\title{
CHOCOLATE E TURISMO: O PERCURSO HISTÓRICO EM GRAMADO, RS
}

CHOCOLATE AND TOURISM: ITS HISTORY IN GRAMADO, BRAZIL

CHOCOLATE Y TURISMO: SU HISTORIA EN GRAMADO, BRASIL

Me. Daniela Pereira de Vargas Mestrado em Turismo, na Universidade de Caxias do Sul. Docente do SENAC-RS.

\begin{abstract}
Dra. Susana Gastal
Bolsista Produtividade CNPq

Professor, pesquisador e orientador no Programa de Pós-Graduação em Turismo e Hospitalidade da Universidade de Caxias do Sul.
\end{abstract}

Data de Submissão: 04/05/2014 Data de Aprovação: 02/03/2015

RESUMO: Gramado, no Rio Grande do Sul, integra a lista de destinos indutores do Turismo no Brasil, criada pela autoridade federal da área. Tal classificação é resultado de esforços locais contínuos ao longo do século XX para atrair visitantes. Em sua etapa mais recente, o chocolate ganhou centralidade nesse processo. Nesses termos, o presente estudo teve por objetivo descrever a trajetória histórica do Turismo e do Chocolate na cidade, para avaliar suas implicações mútuas ao longo do processo. Metodologicamente associada à História Oral, a pesquisa ${ }^{1}$ 
teve como fonte dados documentais, 15 entrevistas com sujeitos envolvidos com a produção do chocolate e depoimentos de outros sujeitos em publicações locais sobre a presença do turismo na cidade. Os resultados mostram que os turistas são presença na cidade desde seus primórdios, consolidando-se nos anos 1920-1930. Os anos 1950 marcaram-se por iniciativas institucionais públicas e privadas para ampliar essa presença. A partir dos anos 1970, a iniciativa então ousada e isolada de um empresário de instalar uma fábrica de chocolate caseiro na cidade deflagrou novo momento no processo, com fortes implicações no turismo e na economia local.

PALAVRAS-CHAVE: História do Turismo. Chocolate. Gramado. Brasil.

ABSTRACT: The Brazilian town of Gramado is listed, by the federal authority, as one of the most important tourism destinations in Brazil. This classification is the result of local efforts to attract visitors, promoted throughout the twentieth century. In its latest phase, chocolate has become central to this process. This study reconstructs the historical trajectory of Tourism and Chocolate in the town, and evaluates the mutual implications of this process. Methodologically associated with oral history, the research is based on documentary evidence, on fifteen interviews with people involved in the production of Chocolate, and on written statements of other subjects on the presence of Tourism. The results indicate that tourism has existed in the town since its beginnings, becoming more consolidated in the 1920s and 1930s. The 1950s were marked by public and private institutional initiatives to expand the tourism industry in the town. From the 1970s, the initial and isolated initiative of a businessman setting up a chocolate factory in the town sparked a new point in the process, with strong implications for tourism and the local economy.

KEYWORDS: Tourism History. Chocolate. Gramado. Brazil. 
RESUMEN: La ciudad brasileña de Gramado, en el sur de Brasil, fue incluida por las autoridades federales en la lista de los destinos turísticos más importantes del país. Esta clasificación es el resultado de un esfuerzo local promovido durante todo el siglo XX para atraer a los visitantes. En su última fase, el chocolate ganó centralidad en este proceso. Este estudio tuvo como objetivo reconstruir la trayectoria histórica de Turismo y Chocolate en la ciudad y evaluar las implicaciones mutuas en todo el proceso. El estudio está metodológicamente asociado con la historia oral y pretende reconstruir la trayectoria de la presencia del chocolate en el municipio de Gramado y su relación con el turismo. La investigación se basa en parte en pruebas documentales, quince entrevistas con personas involucradas en la producción de chocolate y declaraciones escritas de otras sobre la presencia del Turismo. Los resultados indican que los turistas son presencia importante en la ciudad desde sus inicios, consolidándose en los años 1920-1930. La década de 1950 estuvo marcada por iniciativas institucionales públicas y privadas para ampliar su presencia. Desde la década de 1970, la iniciativa inicial y aislada de un empresario de instalar una fábrica de chocolate en la ciudad provocó un nuevo momento en el proceso, con fuertes implicaciones para el Turismo y la economía local.

PALABRAS CLAVE: Historia del Turismo. Chocolate. Gramado. Brasil.

1 A pesquisa "Turismo e Imaginário: O Percurso Histórico do Chocolate em Gramado/RS", que dá origem ao presente artigo, esteve entre as três indicadas para o prêmio Dissertação Destaque 2014, da Associação Nacional de Pesquisa e PósGraduação em Turismo - ANPTUR 


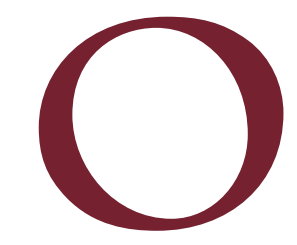

s estudos sobre os processos de institucionalização do turismo nas localidades ainda apresentam pouca ênfase histórica e, quando acontece, o enfoque prioriza a presença da atividade na Europa (BOYER, 2003; URRY, 1999; e, em alguns pontos, REJOWSKI, 2002). Towner (1995, p. 339), de certa forma, está entre os atentos à questão, quando alerta:

A visão convencional do passado do turismo é dominada pela história da experiência cultural ocidental. [...] deve ser dada maior atenção ao passado do turismo em sociedade e culturas não ocidentais e às práticas comuns e rotineiras de setores mais amplos da população ${ }^{1}$. (Tradução nossa).

Nesse cenário, mesmo uma publicação especializada, como o Journal of Tourism History (WALTON, 2009), em suas diferentes edições tem se concentrado em textos que analisam o histórico da atividade na Europa e no entorno do Mediterrâneo, sendo poucos os artigos a abordar o turismo e as viagens em outros continentes. Da mesma maneira, pesquisas sobre os primórdios das viagens e do turismo no Brasil são mais raras ainda².

No que se refere ao conteúdo das pesquisas realizadas na área, a história das viagens pode ser separada da história do turismo, mais propriamente. A história das viagens reuniria as experiências individuais de viagem, enquanto a história do turismo abordaria a "[...] forma como se prepararam as localidades turísticas, como se constituíram os serviços de alimentação e de hospitalidade em geral, como se organizaram os roteiros e guias a serem seguidos pelos viajantes [...]" (SIQUEIRA, 2008, p.120), estudos estes que seriam ainda mais escassos do que os primeiros. Seguindo tal sistematização, a pesquisa aqui relatada centra-se na história do turismo na cidade de Gramado, situada no extremo sul do Brasil, resgatando seus primórdios na primeira metade do século XX e a sua maturidade nas décadas que se sucederam.

Listada pelo Ministério do Turismo (2011) entre os destinos indutores do turismo no Brasil e apresentada pela sua Prefeitura Municipal (2011) como o terceiro destino mais desejado do Brasil, Gramado não foge à regra ao não 
apresentar textos de maior consistência acadêmica no registro do percurso histórico que a elevou a esse patamar. Relatos locais (GRAMADO,1999; DAROS, BARROSO, 2000) indicam que, após iniciativas isoladas na primeira metade do século XX, a partir da emancipação política do município, nos anos 1950, o desenvolvimento do turismo na localidade foi estimulado por ações de empreendedores locais e por uma política de realização de eventos, que uniu autoridade pública, iniciativa privada e comunidade, com destaque para a introdução do chocolate, a partir dos anos 1970. Na primeira década do século XXI, esse produto atingiu dimensões que o tornaram um bem turístico da cidade, fato identificado na pesquisa de Da Rosa (2006), que apontou ser o chocolate um dos itens de expectativa para retorno à região, ao lado das malhas, do couro e do artesanato.

$\mathrm{Na}$ atualidade, o chocolate associa-se indelevelmente à marca Gramado e as lojas de comercialização do produto pontuam sua paisagem urbana. 0 chocolate apresenta consumo em ascensão, conforme dados do Gramado. Canela Convention\&Visitors Bureau, levantados em pesquisas de satisfação realizadas em 2012, 2013 e 2014, como mostram os gráficos nas figuras de número 1,2 e 3.

Figura 1: Pesquisa de Satisfação, Gramado 2012
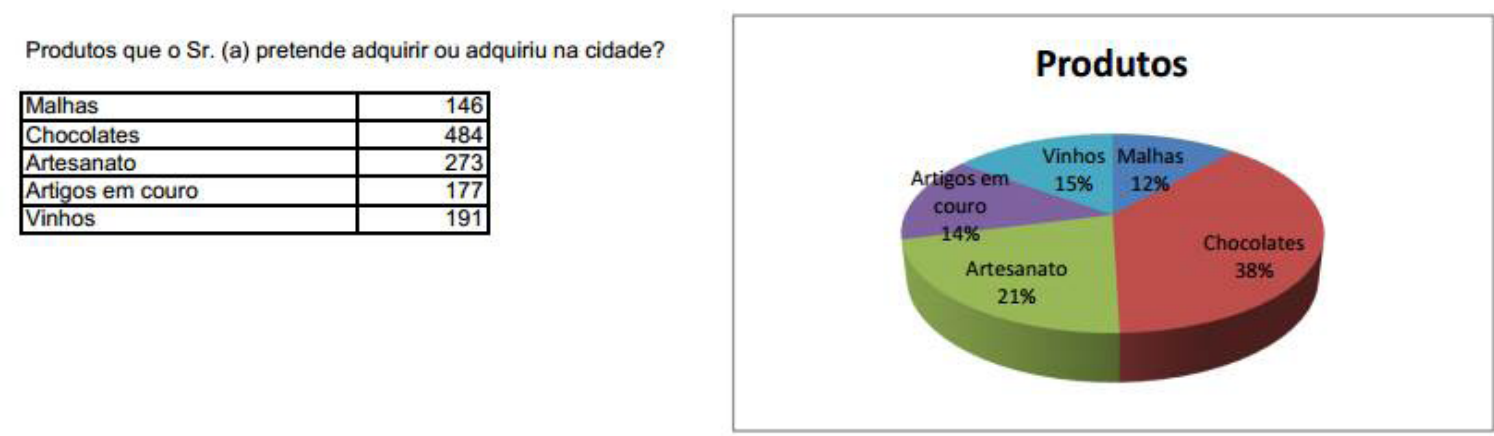

Fonte: Gramado.Canela Convention\&Visitors Bureau³ .

No último triênio o chocolate passou de $38 \%$ na intensão de compra, em 2012, para 43\% em 2013, à frente de outros produtos tradicionais da cidade, como o artesanato, as malhas, os vinhos e os produtos em couro. 
Figura 2: Pesquisa de Satisfação, Gramado 2013

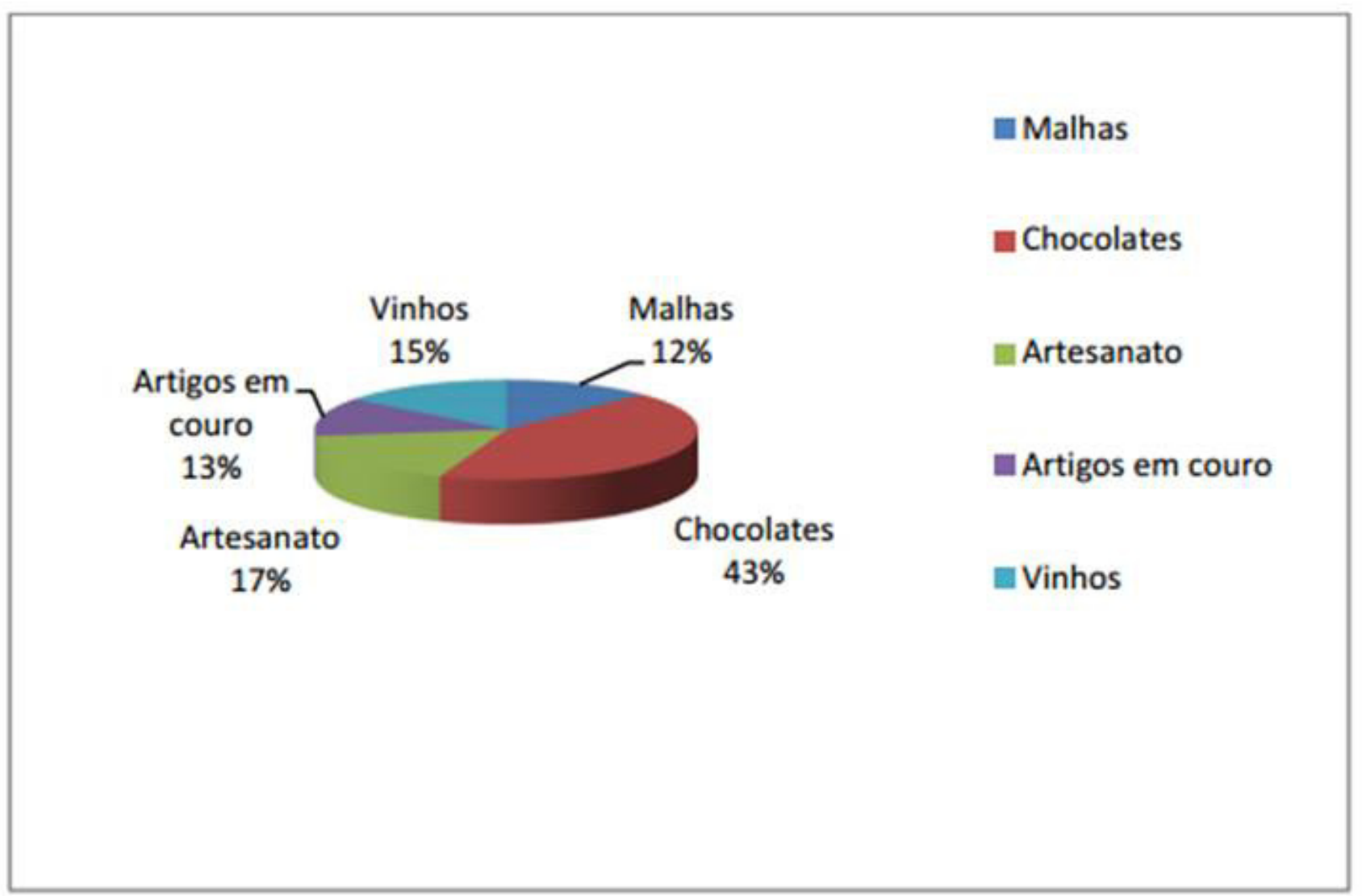

Fonte: Gramado.Canela Convention\&Visitors Bureau4 .

A sistemática de apresentação da pesquisa muda em 2014. O gráfico agora é construído a partir de números absolutos e não mais de percentuais, mas como pode ser observado na Figura 3, o chocolate mantém considerável distância de preferência, à frente de outras intensões de compra pelos turistas. 
Figura 3: Pesquisa de Satisfação, Gramado 2013

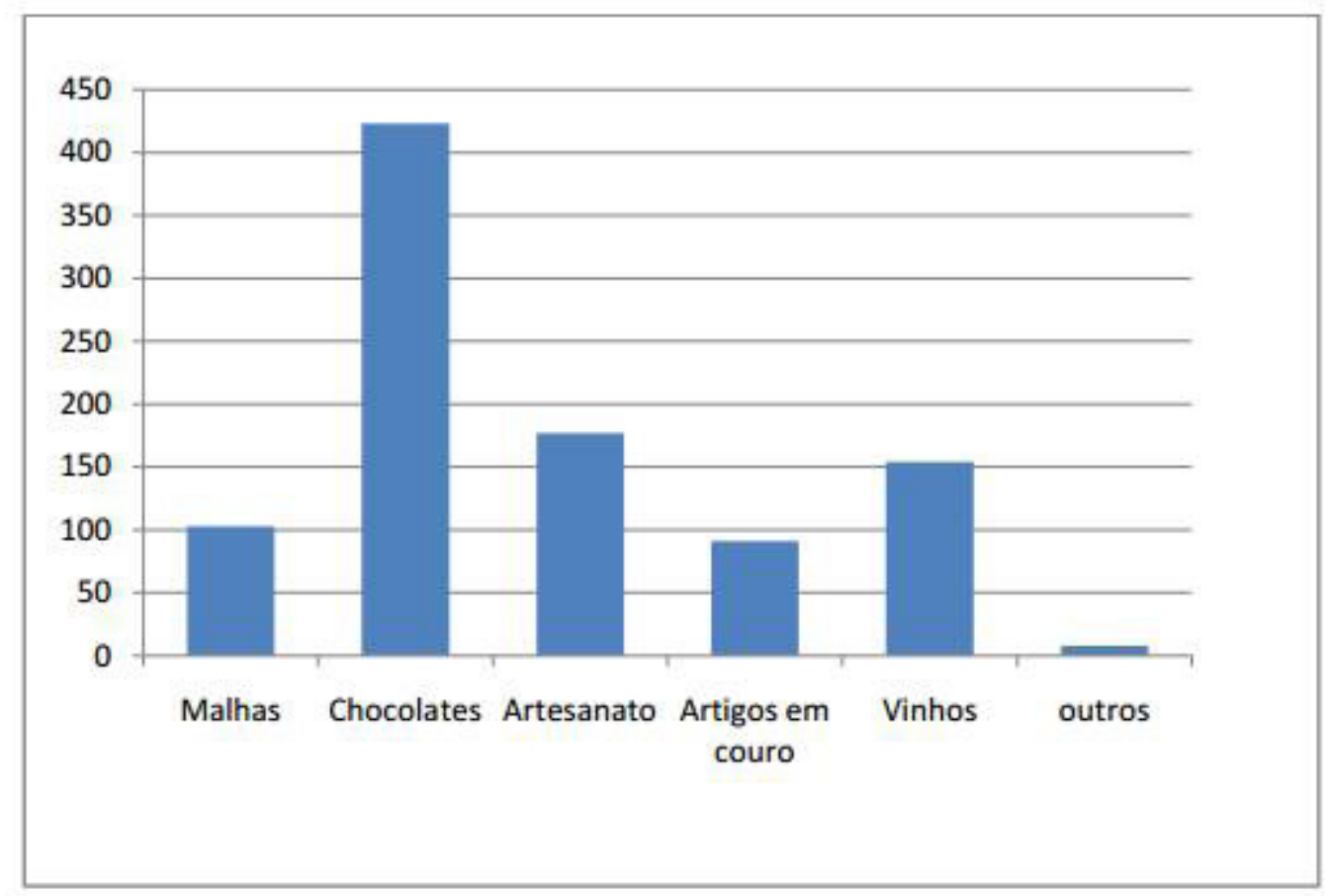

Fonte: Gramado.Canela Convention\&Visitors Bureau ${ }^{5}$.

O presente artigo tem por objetivo, portanto, reconstruir a trajetória da presença do chocolate na cidade da Serra Gaúcha, assim como refletir sobre a maneira como o mesmo mantém relações de dependência mútua com o turismo. O procedimento metodológico compreendeu as seguintes etapas: (1) coleta de informações por meio de revisão bibliográfica; (2) coleta de dados por meio de registros escritos, folhetarias e páginas eletrônicas das empresas fabricantes de chocolate em Gramado; (3) reunião de depoimentos escritos e entrevistas com os sujeitos da pesquisa; (4) análise e discussão dos obtidos. Considerou-se o proposto por Towner (1988), quando destaca que dados importantes para os estudos históricos (historical studies) podem ter origem nas seguintes fontes: estatísticas (statistical records); documentos pessoais (personal documents), como cartas, diários e depoimentos escritos; registros em meios de comunicação de massa (mass communication records), em especial jornais, revistas, folhetos, guias de viagem, cartoons e outras imagens; bem como pesquisas já realizadas sobre o tema.

Metodologicamente, o estudo afilia-se à História Oral, "método de pesquisa (histórica, antropológica, sociológica, etc.) que privilegia a realização de 
entrevistas com pessoas que participaram, ou testemunharam, acontecimentos, conjunturas, visões de mundo, como forma de se aproximar do objeto de estudo." (ALBERTI, 2004, p. 18). Utilizada como fonte para interpretar e compreender o passado, aproxima as falas dos sujeitos, documentos escritos, imagens e outros tipos de registro, valorizando as memórias e as recordações individuais, em especial quando da ausência de outras fontes. Pode dar-lhes tratamento, portanto, como fontes primárias.

Para a presente pesquisa, foram particularmente valiosos, além das entrevistas, os depoimentos de próprio punho de moradores e ex-moradores da cidade presentes nos livros Raízes de Gramado (Gramado, 1999) e Raízes de Gramado: 40 anos (DAROS; BARROSO, 2000) ${ }^{6}$. Foram realizadas 15 entrevistas ${ }^{7}$ temáticas (ALBERTI, 2004) com pessoas selecionadas, considerando-se sua posição em relação ao tema em estudo. As entrevistas foram realizadas de forma aberta e em conversa amigável, seguindo um roteiro que questionava como o entrevistado testemunhara ou participara da história do chocolate em Gramado. As entrevistas foram registradas digitalmente e degravadas na sua íntegra para posterior consolidação no texto do trabalho; tais falas são introduzidas, no presente texto, em itálico, para destaque.

Dada a ausência de registros estatísticos de documentos ou de outros registros oficiais sobre os temas chocolate e turismo, tanto no Arquivo Público Municipal Leopoldo Lied, como na Biblioteca Pública Municipal Ciro Martins ou no Museu Municipal Professor Hugo Daros, todos na cidade de Gramado, seguiuse Towner (1988), utilizando como fonte de dados os meios de comunicação e de divulgação (folhetarias e páginas eletrônicas das empresas fabricantes de Chocolate $^{8}$ ) e os já citados depoimentos em livros, além das entrevistas.

Para fins da presente discussão, considera-se o turismo a partir do proposto pelo Ministério do Turismo (2011, p.4) que, seguindo a Organização Mundial de Turismo (OMT), caracteriza-o como as "atividades que as pessoas realizam durante viagens e estadas em lugares diferentes do seu entorno habitual, por um período inferior a um ano, com finalidade de lazer, negócios e outras". Beni (2007) complementa esse conceito quando descreve o turismo sob uma lógica que interessa especialmente ao presente estudo, qual seja, a de vê-lo como 
um 'processo de decisão' complexo, por incluir itens como 'o que visitar', mas também a 'realização pessoal e social' do viajante, questões que extrapolam a viagem, mais propriamente levando a que certos elementos - o chocolate, por exemplo -, num primeiro momento não necessariamente associados ao turismo, tornem-se fundamentais em processos de turistificação. Nas palavras do estudioso, o turismo é:

[...] um elaborado e complexo processo de decisão sobre o que visitar, onde, como e a que preço. Nesse processo intervêm inúmeros fatores de realização pessoal e social, de natureza motivacional, econômica, cultural, ecológica e científica que ditam a escolha dos destinos, a permanência, os meios de transporte e o alojamento, bem como o objetivo da viagem em si para a fruição tanto material como subjetiva dos conteúdos, sonhos, desejos, de imaginação projetiva, de enriquecimento existencial histórico-humanístico, profissional, e de expansão de negócios. (BENI, 2007, p.37).

Considerando Beni (2007) e retomando Towner (1988), a postura de pesquisa sobre a presença do chocolate em Gramado será a do cientista social, que busca desenhar o cenário histórico e turístico da atividade na localidade ao longo da segunda metade do século XX e décadas seguintes. Nessa linha sociológica, destaca-se que haveria diferenças entre o olhar do historiador e o do cientista social, como registrado por Towner (1988, p. 50):

[...] um estudo sobre o turismo no passado pode visar, principalmente, fornecer exemplos que irão contribuir para um modelo dinâmico ou conceitual do papel do turismo nas sociedades em geral. Em outras palavras, o objetivo do historiador é o de reconstruir a realidade de um período passado particular ou de um evento, enquanto o cientista social busca desenvolver conceitos mais gerais da sociedade, onde a historicidade específica do dado não é questão central [...]..$^{9}$ (Tradução nossa).

Considera-se, assim, que para o entendimento sociológico do percurso temporal da presença do turismo nas localidades, a partir da (re)constituição histórica da atividade no local, busca-se contextualizá-lo como um processo e não como um fato isolado e datado. Inicia-se por uma descrição da presença de atividades de turismo na localidade, para a seguir acompanhar a introdução do chocolate nesse processo, alçado a motivo para visita ao local. 
Gramado integra a região turística Serra Gaúcha, no extremo sul do Brasil, sendo um dos principais polos turístico do país. A cidade teria recebido, em 2012, cerca de 5,7 milhões de visitantes ${ }^{10}$, número bastante significativo se comparado aos seus 34.365 habitantes ${ }^{11}$. A localização geográfica, a $830 \mathrm{~m}$ de altitude, lhe confere paisagens acidentadas e um clima úmido e temperado, que no inverno apresenta temperaturas próximas ao $0^{\circ} \mathrm{C}$, marcadas por geadas e alguns episódios de neve. Crônicas e outros escritos sobre os primórdios da cidade registram que a ela teria se 'inventado' e continuaria a se 'reinventar' como destino turístico, entre outros, com ações locais e campanhas publicitárias que, a partir dos anos 1960, empenharam-se em associá-la a um imaginário de 'Europa brasileira', além de buscar torná-la um destino 'romântico' (GRAMADO, 1987).

Território originalmente ocupado por indígenas, a partir de 1875 estabeleceram-se ali famílias luso-açorianas que exerciam atividades associadas ao tropeirismo, advindo daí, inclusive, sua denominação, então referindo a um gramado, próximo a um riacho, que servia de área de descanso para tropeiros e carreteiros em trânsito pela região (RIEGEL, 2000). Nos anos seguintes, os europeus vindos da Península Itálica estabeleceram-se no interior do município como produtores rurais. Os germânicos, de maneira especial aqueles já residentes desde as décadas iniciais do século XIX na capital regional, Porto Alegre, teriam chegado a Gramado apenas anos mais tarde, já no início do século XX, adotando a cidade como local de segunda residência. Tal presença multicultural será, de certa forma, apagada pelo imaginário que a associa a germanidade, na segunda metade do século XX, em especial na publicidade turística (FIGUEIREDO, 2009). ${ }^{12}$

O lugarejo colonial cresceu, atraindo visitantes e veranistas motivados pela qualidade paisagística do local e pelo seu clima ameno, considerado como propício à saúde e ao tratamento de doenças respiratórias. Os cronistas registram que os "[...] efeitos benéficos se tornaram conhecidos e o fluxo de pessoas de cidades grandes se tornou intenso, marcando a presença de um tipo especial de população" (DAROS, 2000, p. 26). A presença dos veranistas era maior no 
período entre os meses de dezembro a fevereiro - e daí a palavra -, indo para passar alguns dias ou toda temporada de verão.

Desde então, a hotelaria teria papel relevante no desenvolvimento local, em especial após a chegada do trem à localidade, em 1921 (Figura 4).

Figura 4: Gramado recebe o trem em 1921

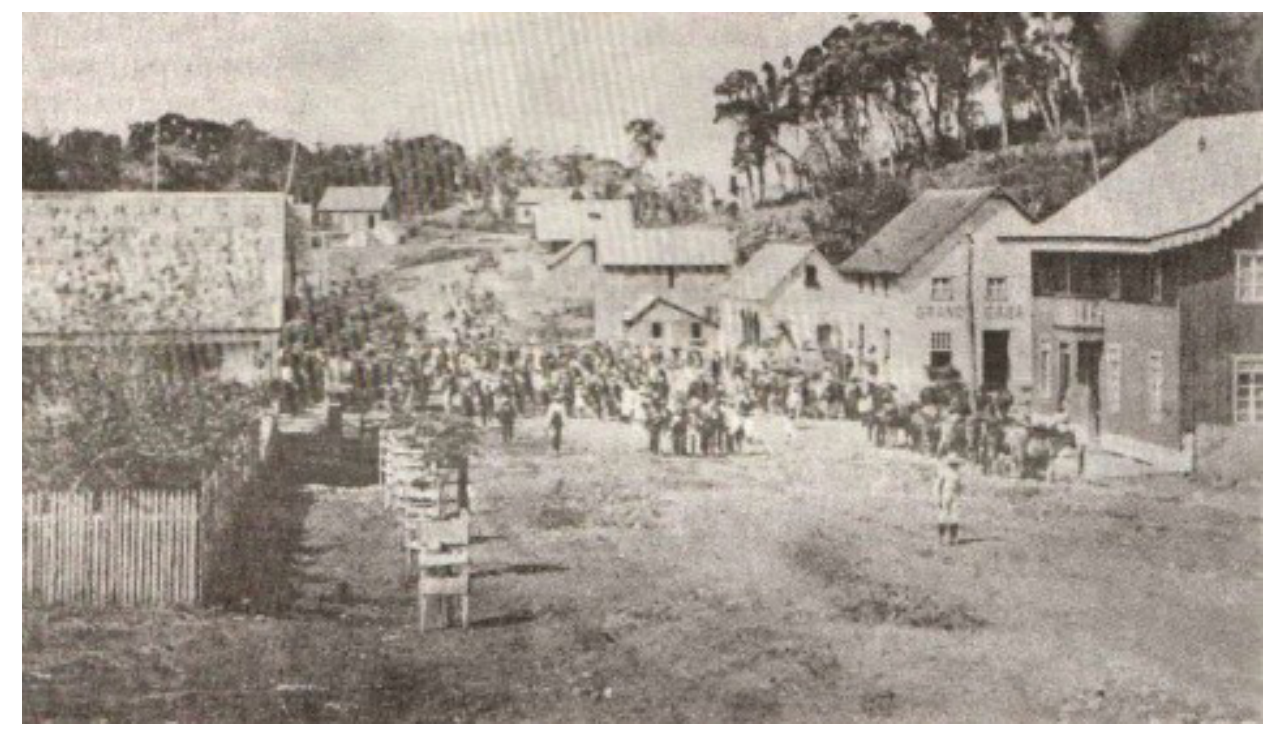

Fonte: Gramado Magazine ${ }^{13}$.

Em termos de hotelaria, em 1918, Henrique Bertolucci abriu o hotel que levaria seu nome, cujas instalações limitavam-se a duas camas de ferro e duas camas de lona (KOHUT et al., 2000). Em 1930 (Figura 5), João Fisch Sobrinho instala o segundo hotel e Bertolucci amplia o seu, que passa a oferecer 50 quartos. Na década de 1940, outros empreendedores investem no ramo hoteleiro (CASAGRANDE, 2006). Interessante que, em documento de 1941 (GRAMADO, 1987, p.43), o Hotel Bertolucci destaca que "não se aceitam doentes" e o Fisch, que seria "próprio para veranistas e viajantes", o que parece indicar o fim do turismo de saúde na cidade. O Fisch tinha capacidade para até 200 hóspedes, com pensão completa, ou seja, incluindo as refeições (DAROS, 2000). Sobre esse período, Behrend (1999, p.189) comenta:

Gramado era uma pequena Vila, mais habitada por italianos do que alemães e possuía quatro hotéis que ficavam em sequencia na Avenida Borges de Medeiros, partindo do Quiosque da Praça, onde ficava o Hotel Fisch, depois o Candiago, no lugar do Serra Azul, seguindo pelo Hotel Bertolucci e terminando com o Hotel Sperb [...]. 
Figura 5: Avenida Borges de Medeiros, década de 1930

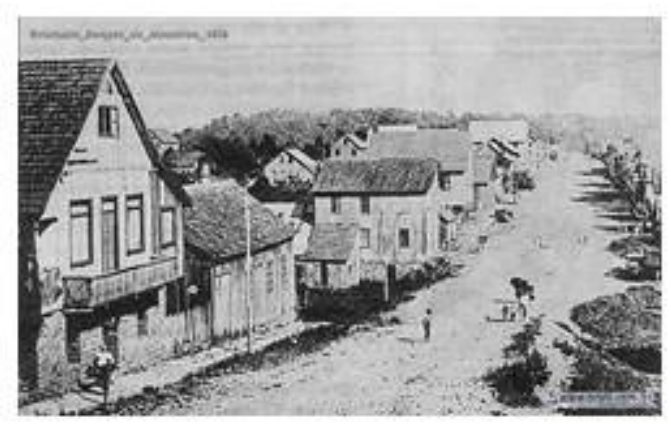

Fonte: Gramado Magazine ${ }^{14}$.

Gramado beneficia-se das facilidades proporcionadas pelo trem, contrapostas à dificuldade de acesso a outros pontos do Estado, como ao litoral ou às estâncias termais no norte. Há outra razão para o crescimento da presença de turistas no período das grandes guerras europeias: "[...] as praias [junto ao oceano] estavam fechadas ao público, por motivo de segurança nacional, fato que colocou Gramado como opção de veraneio." (BERTOLUCCI, 1999, p.63).

O cenário de prosperidade fez emergir, em 1942, o loteamento Vila Planalto, com foco no turismo de segunda residência, empreendimento que tinha sob sua direção Leopoldo Rosenfeldt. Para qualificar a área do loteamento, Rosenfedt a reflorestou: "Nas margens [do Lago Negro] foi feito um trabalho de paisagismo, alterando ciprestes (escuros) com álamos (claros). Plantou ainda azaléas e araucárias, colocando, na beira do lago, xaxins. Para que os visitantes pudessem tomar banho de sol, fez uma praia de areia" (Idem, p. 65). Para divulgar o empreendimento, criaria, ainda, o que seria o primeiro roteiro turístico da cidade, "denominado Gramado, Maravilha do Veraneio. Também fez o primeiro trabalho organizado de divulgação do turismo de Gramado em Porto Alegre e no Rio Grande do Sul" (Idem, p. 64), pois dentro do loteamento, "[...] haviam sido destacados os pontos turísticos [...] Lago do Parque Hotel, Praça da Montanha, Vista Belo Horizonte, Lago Negro, Cascata dos Narcisos (Figura 6) e Véu das Noivas" (Idem, p. 64). 
Figura 6: Cascata dos Narcisos, década de 1940

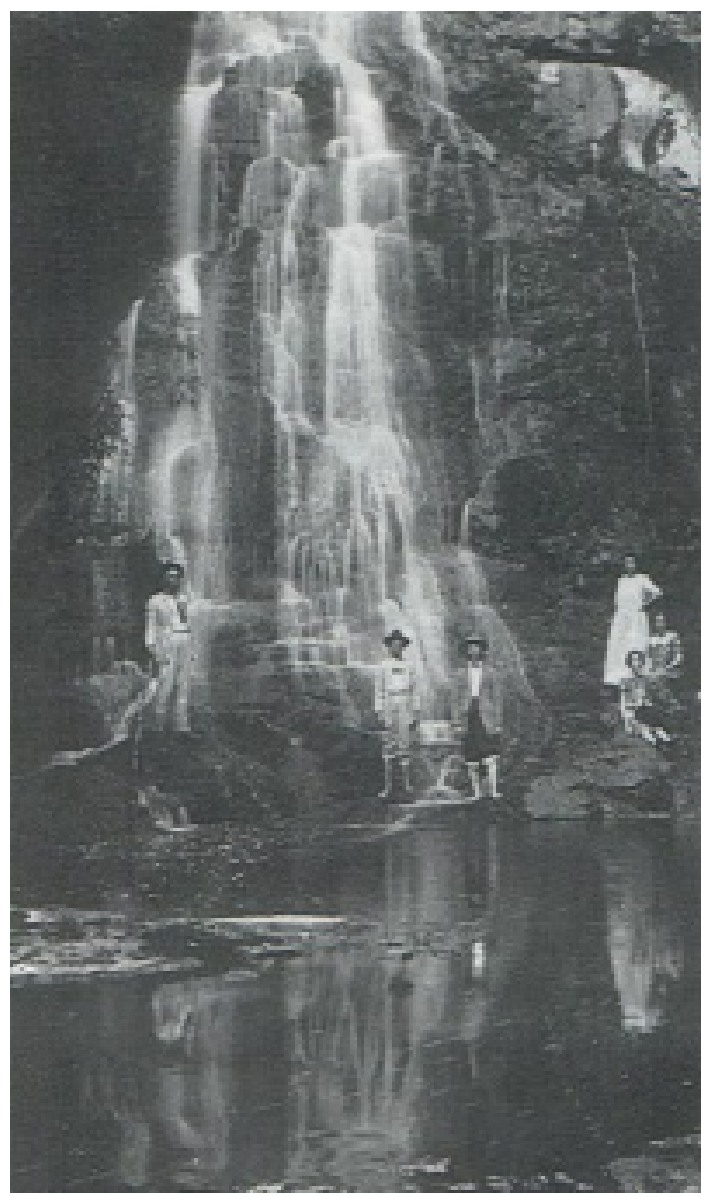

Fonte: Gramado Magazine ${ }^{15}$.

Mas a trajetória do turismo no local não aponta apenas momentos de sucesso, como se observa com a situação da estrada de ferro, ligando os municípios de Taquara e Canela, que entre os anos 1920-1950 foi fundamental para o desenvolvimento da região. No primeiro momento, "[...] o trem só chegava até Gramado. Não querendo fazer uma desconfortável viagem até Canela, os visitantes ficavam aqui [em Gramado] e lotavam nossos inúmeros hotéis [...]" (RIEGEL, 2000, p.26), segundo Casagrande (2006), motivados pela hospitalidade, pela gastronomia e pela paisagem, que lembraria a Europa. Num segundo momento, a extensão da linha férrea até Canela levou à diminuição da presença de visitantes em Gramado, pois "[...] muitos turistas preferiram descer no fim da linha." (RIEGEL, 2000, p.27). Com isso, "Canela prosperou, tendo surgido vários bons hotéis. Até um cassino começou a ser construído." (Idem). A desativação da linha férrea atingirá profundamente os dois municípios. Acrescente-se a isso que "ao lado do mar, tão distante, estava sendo edificada outra estrutura turística e que esta seria a ruína de ambos." (RIEGEL, 2000, p. 27). 
A mobilização da comunidade para alterar tal cenário se dá, primeiro, na busca do reconhecimento de Gramado como município, o que acontece em 1954 (RIEGEL, 2000; CASAGRANDE, 2006; DALONSO; LOURENÇO; REMOALDO; CYRILLO, 2012). A seguir, estimulam-se ações para tentar reverter a queda no número de visitantes. Em 1958, Prefeitura, iniciativa privada ${ }^{16}$ e comunidade promovem a $1^{\circ}$ Festa das Hortênsias, tendo como tema a flor, muito cultivada no local, no mesmo propósito de atrair turistas, mas muito especialmente promover o retorno dos antigos veranistas. "Esse acontecimento colocou os veranistas no passado. De agora em diante eles estavam promovidos a turistas, cabendo um esforço permanente para atraí-los, no verão e no inverno." (RIEGEL, 2000, p.29).

A partir da década de 1960, Gramado e Canela defrontam-se não só com a desativação da linha férrea, como com a concorrência com o Litoral, que ganhou melhores condições de acesso nesse período.

Para enfrentar a concorrência da praia, os nossos hotéis tinham que se modernizar. O próprio setor público exigia, por exemplo, melhores condições sanitárias. Como já tinham empobrecido, nossos hoteleiros não se modernizaram e quebraram todos, com exceção do Parque Hotel. (RIEGEL, 2000, p. 27).

Anos depois, em 1973, virá outra queda para o turismo na cidade, quando a "[...] primeira crise do petróleo e algum tempo depois o racionamento de gasolina [leva ao] fechamentos dos postos nos finais de semana. [...] As vendas diminuíram sensivelmente [...]", segundo a designer Renata Rubim (1999, p. 182), que na época atuava no Artesanato Gramadense, empresa criada por Elizabeth Rosenfeldt em 1964. O Artesanato Gramadense produzia tapetes na sua tecelagem e móveis em madeira, seguindo uma tradição moveleira local que reportava a 1945. Mas será com Rosenfeldt que esse ramo industrial se tornará referência pela qualidade de seus produtos, associados à marca Gramado. Rosenfeldt inova, especialmente nos móveis, ao introduzir a "[...] Linha Rustico Colonial, uma linha que mais tarde ficou conhecida com o nome de Móveis de Gramado." (DINNEBIER, 1999, p. 170). A empresa não se limitava aos móveis e aos tapetes:

A marcenaria fabricava desde móveis pequenos até imensos, roupeiros, estantes. De lá também saíam as miudezas que enchiam os olhos de todos. Eram quadrinhos, castiçais, luminárias, pratos e 
travessas, talheres de saladas, caixas, gamelas, revisteiros, um mundo onde a imaginação não tinha limites. (RUBIM, 1999, p. 181).

Renata Rubim (1999, p.182) ainda conta no depoimento no livro Raízes de Gramado que o "número de turistas nos finais de semana aumentava consideravelmente". A iniciativa de Rosenfeld fez surgir outros artesãos autônomos e levou a que outras fábricas de móveis fossem instaladas, seguindo o modelo e a estética por ela criados, levando a que, no final dos anos 1980, houvesse 31 estabelecimentos do gênero e, no final dos anos 1990, o número chegasse a 130 em atuação (GRAMADO, 1987). Hoje, seriam 100 as indústrias moveleiras ${ }^{17}$.

Não menos importante foi a indústria de malhas com características artesanais "[...] e diferencial mercadológico fortíssimo [...] [que era] escoada integralmente no período de inverno, pelos turistas que visitam Gramado." (BERTOLUCCI, 1999, p. 173). Fruto inicial das marcas Annerose e Lucirene, no primeiro momento, elas "colaboraram juntamente com o artesanato, o chocolate, móveis, hotelaria e gastronomia para definir o posicionamento de Gramado como centro de turismo [...]." (Idem).

A crescente produção levou a realização da Feira Nacional de Arte (FEARTE), que posteriormente se transformou em evento internacional, contribuindo para uma nova imagem de Gramado (SPARREMBERBERGUER, 2000). Segundo Casagrande (2006, p. 85), o poder público passou a entender que o investimento no turismo "[...] traria ao município a oportunidade de crescimento não só na área econômica como também no campo sócio-cultural. Promoveram eventos arrojados, acolheram eventos econômicos e comerciais de outras localidades e souberam incentivar os eventos criados pela indústria e pelo comércio."

O turismo ingressa em nova fase a partir de 1973, ampliando-se os investimentos no setor, tendo como carro-chefe o Festival de Cinema de Gramado. O Festival, mesmo se dirigindo a um público especializado, tinha alto poder de repercussão na mídia nacional, alavancando consigo a imagem da cidade como destino qualificado e atraindo turistas. Nos anos seguintes, o calendário de eventos do município passou a ser constantemente ampliado, incluindo, além da FEARTE e da Festa das Hortênsias, o Natal Luz e a Festa da Colônia, o Festival de Turismo e a Chocofest, para citar apenas alguns. 
Com todas essas transformações, sucintamente aqui apresentadas, Gramado se posiciona como cidade turística e, cada vez mais, investe para atrair novos visitantes. Na atualidade, o turismo é uma atividade fundamental para economia local, pois $90 \%$ das receitas do município proveem dele, impulsionando os serviços de hospedagem, de alimentação, de transporte, assim como o comércio; os setores industrial e agrícola complementam a arrecadação ${ }^{18}$. (LEMOS; BENI, 2001-2002). Mas, convém destacar, mesmo a indústria coloca parte significativa da sua produção diretamente no local, como registram os depoimentos escritos e entrevistas reunidos pela pesquisa. O peso econômico do turismo, como demonstra o resgate histórico, teria sido alcançado como fruto de esforços e de investimentos locais, tanto públicos como privados, em prol de uma infraestrutura ampla e qualificada ${ }^{19}$. Junte-se a isso a atratividade que seus atributos naturais continuam a exercer (PEZZI, 2013), a promoção de eventos, a variada oferta de produtos coloniais, os artesanatos e, agora, o chocolate dito caseiro (TOMAZZONI; BOCK; SIMON, 2012; GRAMADO²0, 2013) que, mais do que uma oferta gastronômica, se coloca como um bem turístico no sentido apontado por Beni (2007), como será apresentado a seguir.

\section{CHOCOLATE EM GRAMADO}

A presença do chocolate caseiro, em Gramado, inicia na década de 1970, quando o empresário Jayme Prawer implanta no município a primeira fábrica do produto. Prawer é filho de imigrantes vindos da Polônia, que chegaram ao Brasil em 1925, instalando-se em Porto Alegre. Sua ligação com Gramado começou no verão de 1936, quando, com 11 anos de idade, visita um familiar ali residente (PRAWER, 2010). Em 1953, já formado em Odontologia, "[...] ele resolveu vir a Gramado clinicar [...]. Foi o primeiro dentista de Gramado", segundo a filha Nádia Prawer, permanecendo na localidade por três anos, até regresso a Porto Alegre, retornando à cidade como veranista: "Nós vínhamos veranear em Gramado. Nós éramos os legítimos veranistas de Gramado".

Com o tempo, as estadas da família na cidade não se limitaram ao lazer, pois em 1970 Prawer abriu uma churrascaria, a Bela Vista. Apesar de haver um gerente para cuidar do restaurante, pois ele continuava com consultório 
odontológico em Porto Alegre, nas sextas-feiras o empresário se dirigia a Gramado para acompanhar o empreendimento. Em 1972 amplia o negócio, inaugurando o Café Colonial Bela Vista, que por muito tempo foi referência na gastronomia local. Os negócios envolvendo o chocolate começaram a nascer em 1975, ano em que Prawer e sua esposa visitam Bariloche, na Argentina, e conheceram, entre as atrações da cidade, o chocolate caseiro. Essa localidade argentina, aliás, já influenciara a atividade econômica da cidade, quando inspira Anelise Rosenfeldt Bertolucci na criação da Malharia Annerose (GRAMADO, 1987). Nádia Prawer relata que o pai "[...] viu que Bariloche tinha a vegetação, a temperatura, o relevo, todo o clima, toda uma atmosfera muito parecida com Gramado e viu que tinha chocolates caseiros lá.".

Ainda nesta primeira oportunidade, visitou uma fábrica local do produto, cujo proprietário se propôs a disponibilizar seu know-how aos brasileiros. Para viabilizar o negócio no Brasil, Prawer contratou Isidoro Manara, seu cliente no consultório em Porto Alegre e experiente profissional de confeitaria, que fora por dezoito anos funcionário da fábrica de chocolates Neuguebauer ${ }^{21}$. No entanto, esbarrou na necessidade de um maquinário mais especializado, o que não se constituiu em problema para o odontólogo, que passou a desenhar os equipamentos para a fabricação do produto (PRAWER, 2010). Outra dificuldade, essa de mais difícil solução, foi a adequação do produto ao clima local, mais quente que o argentino, embora isso não ficasse evidente para Prawer no primeiro momento. Conforme Norma Martini Moesch, que na época da inauguração da Prawer era membro da diretoria da Secretaria de Turismo do Estado do Rio Grande do Sul:

Eu não sei estimar, mas quero crer que ele levou mais de ano para poder colocar esse produto na rua, depois de dizer: 'A fábrica está pronta' [pois] eles não conseguiram acertar o Chocolate, cujo know how e patente ele comprou em Bariloche. [...] Não conseguiram nivelar ao clima, ou seja, entendendo que a Serra Gaúcha é um local frio e Bariloche é um local frio, esse nivelamento, aparentemente, era suficiente, mas na verdade o frio de lá e o frio daqui [...] eram muito diferentes e daí a tecnologia que precisou importar e por isso custou muito caro essa fábrica dele. Porque ele teve que criar internamente, nas dependências da fábrica, um clima [...] estável o ano todo, como o clima de Bariloche [...]. 
Superadas as dificuldades, no final de 1975 a Prawer iniciava a produção de Chocolate em uma fábrica de $70 \mathrm{~m}^{2}$, onde trabalhavam três artesãos. A primeira loja foi aberta em fevereiro de 1976, coincidindo com o período de realização do Festival de Cinema de Gramado, o que permitiu que a inauguração tivesse repercussão na mídia. O próprio Jayme Prawer é quem recorda: "Quando os jornalistas de todo o país chegaram para o Festival e visitaram nossa Fábrica de Chocolate Caseiro, se entusiasmaram, pois conheciam esse produto apenas de Bariloche; nunca tinham visto nada parecido no Brasil. Foi um estouro, saiu em toda a mídia." (PRAWER, 2010, p. 27).

Figura 7: Primeira sede do Chocolate Prawer

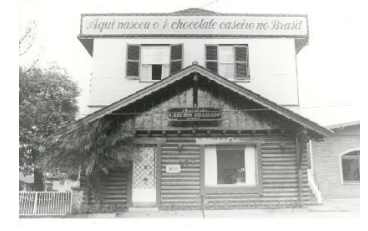

Fonte: Chocolate Prawer Gramado22.

Nádia Prawer complementa: “Foi um sucesso porque além de ser uma coisa inovadora, ah, o pai teve sorte que quando abriu [...] em pleno Festival de Cinema aqui em Gramado, ou seja, toda a mídia do Brasil estava aqui na época, jornal de São Paulo, jornal do Rio, jornal de Porto Alegre [...]". O historiador Gilnei Casagrande apresenta descrição semelhante: "Ninguém conhecia Chocolate, não existia essa magia que tem hoje do Chocolate, o gosto, os sabores, os aromas do Chocolate".

O modelo deu certo e logo outras empresas chocolateiras se juntaram à Prawer, em Gramado, como a Lugano (1976) e a Planalto (1977), número que hoje atinge 19 fábricas $^{23}$. Segundo Nádia, todas tiveram a Prawer como marco inicial: "Começaram a sair pessoas e a colocarem outras fábricas de Chocolate [...] e todos, todos, foram, digamos assim, a raiz. Veio da Prawer, a raiz saiu daqui, do pai". Norma Moesch reforça: "a maior parte dos chocolateiros da região, e não é só Gramado, eles repetem o que a Prawer lança. Eles vão atrás, nas pegadas da Prawer". Para Caio Tomazelli, funcionário da Prawer por cerca de 30 anos: fez a primeira linha de Páscoa; foi a Prawer que lançou o Mentinha24, o 
foundue de Chocolate; o primeiro programa de qualidade foi a Prawer quem fez, o APPCC ${ }^{25}$ [...]; linha especial de Chocolate para hotelaria foi a Prawer quem lançou. Então, todo esse processo de evolução teve muito a ver com a história que a Prawer desenvolveu.

O produto passou a estar diretamente associado à cidade, em parte graças à divulgação, associada ao Festival de Cinema, como já colocado, levando à compra pelos turistas tanto para consumo local como para o levarem como presente ou mesmo como souvenir. Contribuiu para sua divulgação, ainda, o fato de Jayme Prawer viajar para comercializá-lo e, em simultâneo, divulgar a cidade (PRAWER, 2010). Nádia recorda: “Quando o meu pai lançou o Chocolate ele fez aquelas caixinhas que têm até hoje, um pouquinho diferente [...]. Todas as caixinhas eram escritas 'Conheça o Brasil visitando Gramado'. Ele não ganhava nada para isso e não era nem secretário de Turismo". Outras embalagens (Figura 8 e 9), destacavam - e continuam destacando - além da palavra Gramado, marcas da cidade como as Hortênsias e a arquitetura.

Figura 8: Embalagem Prawer destacando as Hortênsias e a palavra Gramado

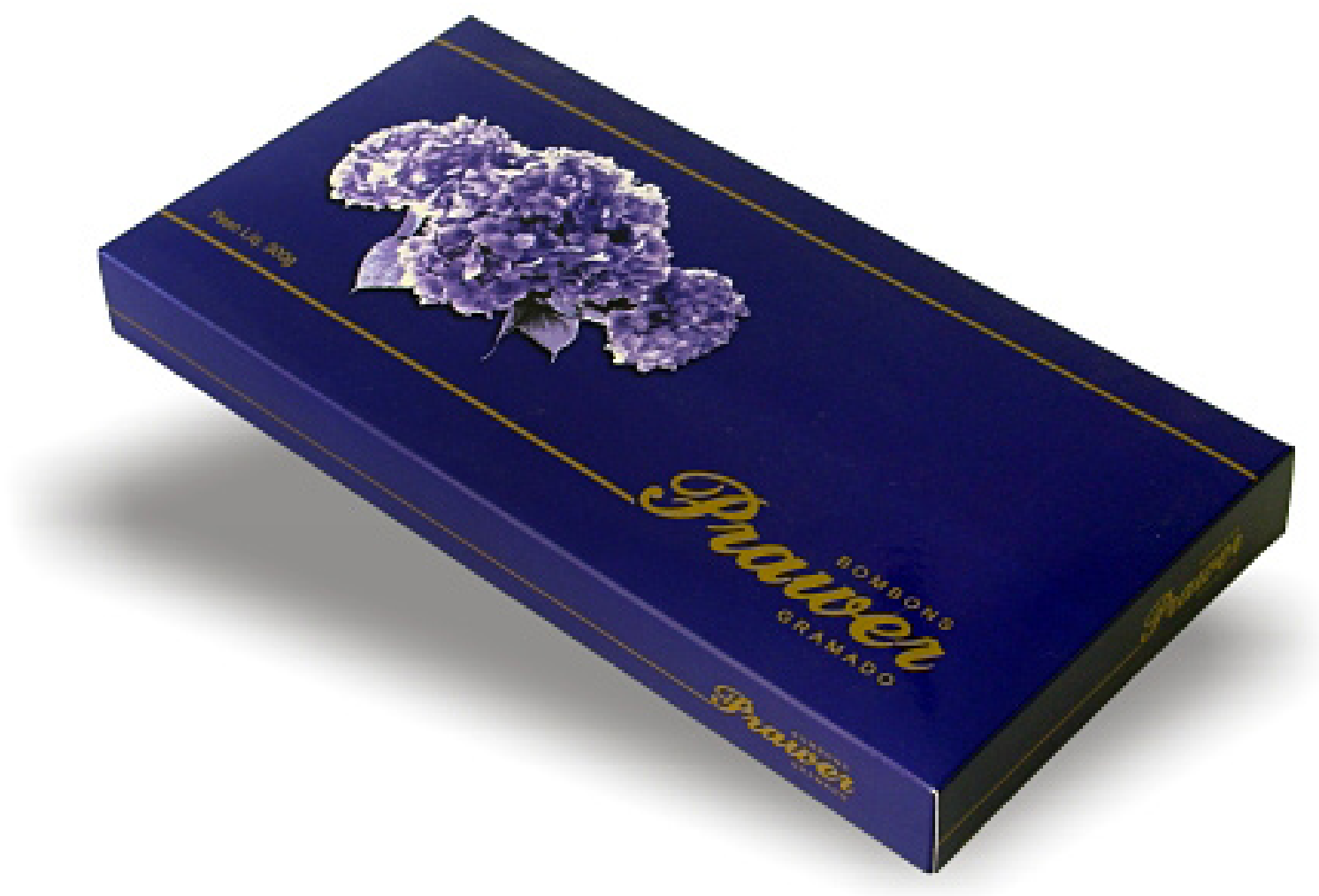

Fonte: Proper Comunicação ${ }^{26}$. 
Figura 9: Embalagem Prawer destacando a arquitetura de Gramado

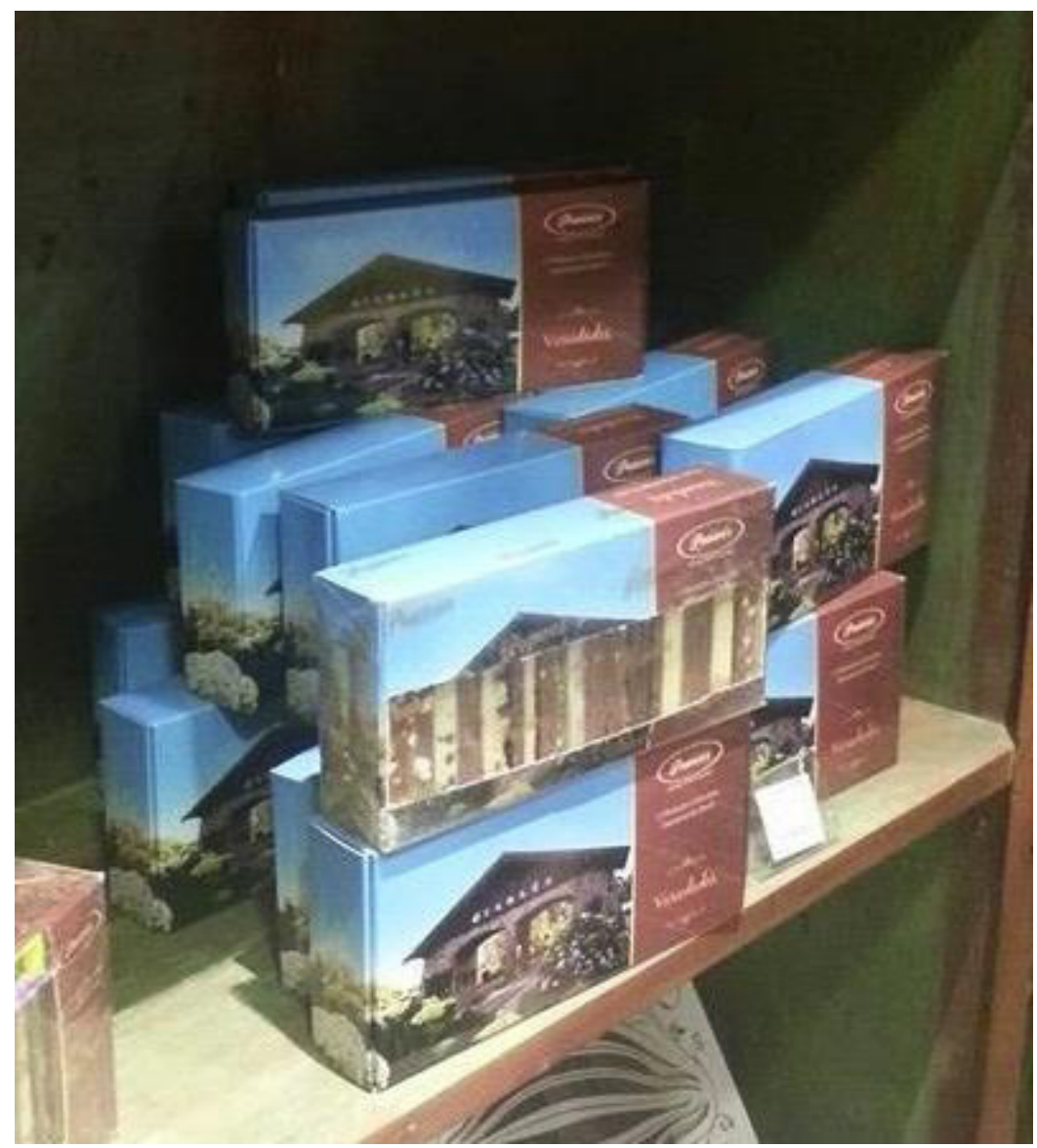

Fonte: http://donnagatta.blogspot.com.br/2012/11/chocolates-prawer-gramado-rs. html.

Os depoimentos colhidos pela pesquisa reforçam que Prawer acreditava no potencial de Gramado e principalmente na consagração que o chocolate poderia trazer à cidade, a exemplo do que acontecia com Bariloche, e trabalhava constantemente nesse sentido, como ele mesmo relata:

Certa ocasião, eu estava em Manaus e conheci um cidadão ligado ao governo da Amazônia. [...]. Imaginava que eu era remunerado pela Prefeitura de Gramado para divulgar tanto a cidade, e ficou surpreso quando Ihe informei que não ganhava nada. (PRAWER, 2010, p.27).

Moesch também descreve o empenho de Prawer em associar sua marca à Gramado, incentivando o turismo no local:

[...] o passo que Gramado deu para levar o produto já numa dimensão em escala, [...] se dá no momento em que o senhor Jayme Prawer faz uma belíssima negociação e coloca o Chocolate de Gramado nos kits de viagem da Varig. Então, a Varig coloca o Chocolate de Gramado 
nos seus hotéis, que eram hotéis de luxo, no frigobar do hotel, aqueles displays cheios de Chocolate de Gramado, com as Hortênsias. A única marca era a Hortênsia. No display, na caixa, tudo era Hortênsia, e os coloca no chiquéssimo voo, o Chocolate para ser apreciado pelos seus passageiros. [...] A Varig era aquele luxo, né, comer o que estava abordo da Varig era aquele luxo. Então, eu acho que essa negociação que o senhor Jayme Prawer fez com a Varig foi o grande salto que Gramado deu para se posicionar no Brasil.

Nádia destaca que, além dessas ações maiores, outras menores também contribuíram com o objetivo de fortalecer o consumo e consagrar o produto:

Ele contratou uma menina, que se chamava Prawete, vestidinha, bem bonita, e ai pendurou uma caixinha e colocava os Mentinhas dentro. Tinha uma pessoa que levava ela em todos os restaurantes, em todos os hotéis para dar, oferecer a Mentinha quando a pessoa estava tomando o cafezinho. Para criar o hábito do consumo desse produto com o cafezinho.

Martina Nunes, que trabalhou em uma dessas ações de marketing da Prawer, relembra:

Eu trabalhei vestida de Mamãe Noel [...], entregava o chocolate nos eventos do Natal Luz. Eu ia naquele camarote vip, que era para o prefeito, para os outros lá que vinham, alguns turistas, algumas pessoas e a gente tinha uns tabletinhos, assim, de Chocolate ou umas trufas bem bonitas [que] a gente entregava nos eventos.

Outras ações de iniciativa de Prawer são relatadas por Caio Tomazelli:

A Prawer, para promover o seu produto, promoveu o nome de Gramado também, e isto ajudou a transformar o Chocolate num presente da cidade. Então, toda a vez que nós saíamos para fazer alguma coisa, o prefeito, enfim, todo mundo de Gramado levava o Chocolate e isso se transformou numa coisa quase obrigatória. Então, o Chocolate tem essa identidade com Gramado.

Essa relação de identidade e de simbologia do chocolate com a cidade é reforçada pela comunidade. A empresária Marta Rossi, por exemplo, relata: " $A$ nossa empresa tem até hoje como hábito, [...] nós damos, primeiro, quando nós chegamos em qualquer reunião, o Chocolate, porque na cabeça das pessoas, a memorização é bárbara. [...] 'Ah! foram vocês que trouxeram o chocolatinho'". 
A segunda empresa local do produto, a Chocolate Caseiro Lugano, foi fundada por Lauri Casagrande em 1976, e vendida em 1985 para Renaldo Henrique Schwingel. Enor Francisco Terres da Luz, diretor da empresa, lembra que, quando da aquisição, "[...] ninguém de nós conhecíamos Chocolate, a gente era um consumidor de Chocolate". Até então trabalhando como bancário, explica que "ainda fiquei dois anos no Banco do Brasil após a compra da Lugano, até se formatar um pouquinho melhor e conhecer um pouquinho mais da Lugano [...]. Mas eu apostei, a coisa começou a acontecer, a gente começou a crescer".

A Lugano também nasceu pequena, na época, em uma área de $70 \mathrm{~m}^{2}$ e com três funcionários. Segundeo Terres da Luz:

[...] em 94, a Lugano mais firme e tendo conhecimento maior, a gente foi para uma feira na França convidado pelo Sebrae [...]. Fui conhecer mais aquelas fábricas da Europa, e daí eu já aproveitei e fiquei por lá conhecendo tudo, além da feira que foi muito importante pra gente ver o estava acontecendo no mercado europeu. [...] Eu fiz um curso dentro de uma das maiores empresas de Chocolate da Europa, que fica na Bélgica, a Barry Callebaut e ali eu tive bastante conhecimento. Eu trouxe muitas ideias e a gente começou a mudar todo esse visual da Lugano. A gente também mudou logo depois o processo de self servisse. (Terres da Luz).

Com o self service as pessoas tinham a liberdade de servir a quantidade e o tipo de chocolate, o que, "[...] naquele período foi um salto muito grande. Eu lembro que a gente aumentou as nossas vendas em quarenta por cento, só com aquela mudança de as pessoas se servirem". Ainda segundo Terres da Luz, "a gente estava atrás do balcão e intimidava um pouquinho as pessoas, então, as pessoas depois que começaram a se servir, elas levavam mais Chocolate".

Outra proposta que ganhou forma, após o curso na Europa, foi o desenvolvimento de produtos utilizando figuras: "Eu via muita figura na Europa e coisa que aqui no Brasil ainda não existia, né. Ninguém fazia figura de Chocolate. O Chocolate hoje é infinito no que tu podes desenvolver." Essas figuras, além de ganharem formas com o chocolate, também deram origem para a criação da loja de fábrica. Terres da Luz comenta que queria, com a loja de fábrica, "trazer esse pessoal para ver como nós produzíamos o nosso Chocolate, mas como a gente está fora do roteiro turístico de Gramado, a gente está dentro de um bairro, 
que é difícil das pessoas virem até aqui, a gente criou esse mascote, esse urso". O urso a que se refere está na fachada da loja localizada junto à fábrica, no bairro Carniel, em Gramado. A ideia se consolidou e, em 3 de dezembro de 2004, foi inaugurada, segundo o depoente, "a primeira loja temática de Chocolate do Brasil". A loja tem como anfitrião o urso, batizado como Luguito. Para Terres da Luz, a proposta é de as "pessoas lembrarem da Lugano e lembrarem do urso".

Figura 10: O urso da Loja Lugano

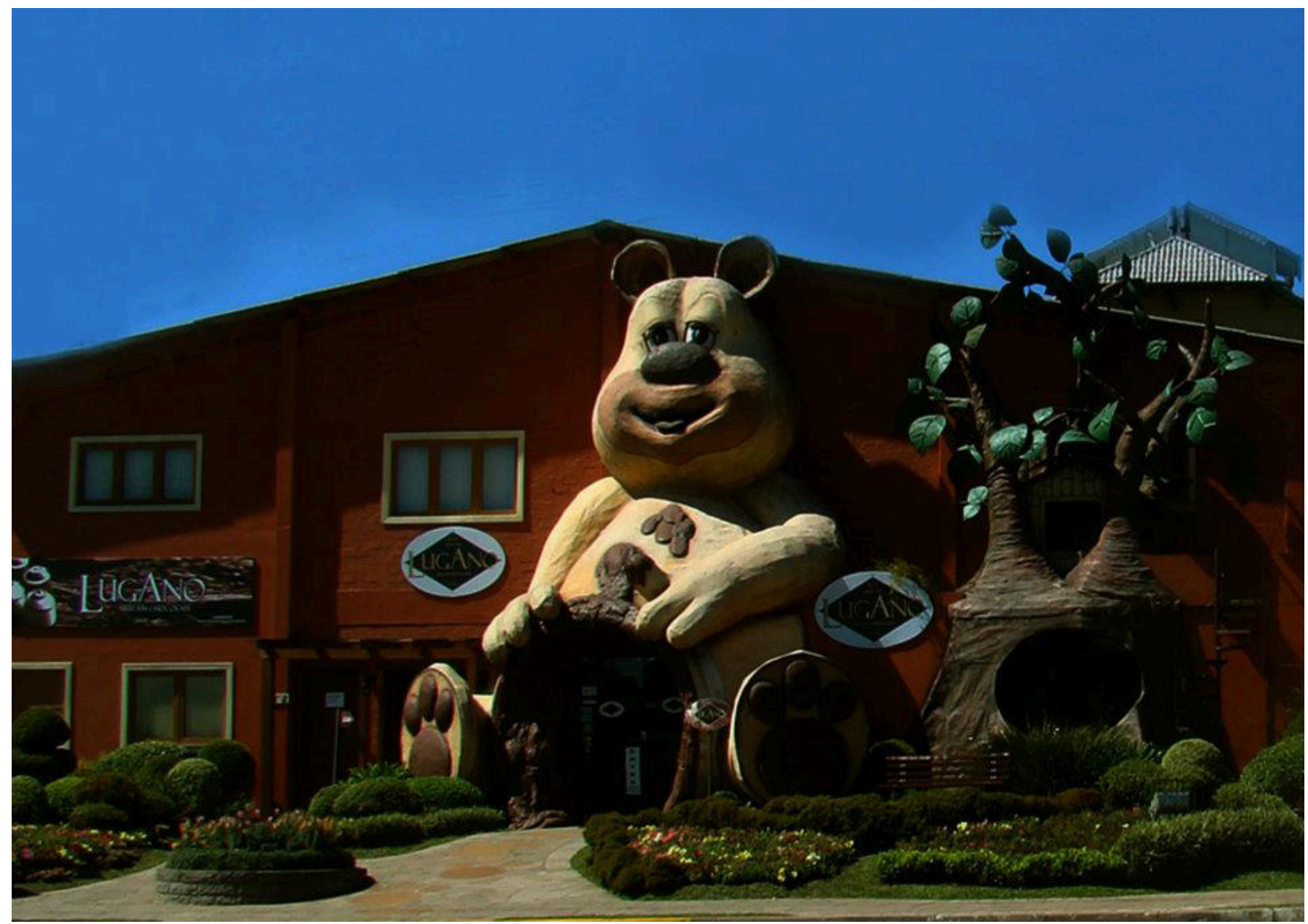

Fonte: Mapa do Mundo ${ }^{27}$.

A terceira empresa criada foi a Chocolate Caseiro Planalto, em 1977, fundada pelo casal Adail e Liria Bortoluci. Segundo Débora Leobet Noel, "[...] o seu Adail trouxe a ideia [...] vamos abrir um negócio e daí ela [Liria] começou a fazer [...] em casa [...]. E daí eles começaram a vender". A empresa permaneceu no bairro Planalto, em Gramado, até o ano de 1984, quando passa por um crescimento significativo, levando à necessidade de mudança, tanto da fábrica como da loja matriz. Em 1989 a empresa muda novamente, para instalar-se numa área de $10.000 \mathrm{~m}^{2}$, onde aumenta a produção e diversificação de seus produtos. 
Em 1993, tendo por estratégia investir no turismo, uma das ações foi a de abrir uma loja no centro da cidade, com uma área de $600 \mathrm{~m}^{2}$ (PLANALTO, 2013). Neste local, além da venda do chocolate, foram incluídos outros atrativos, como cafeteria, sorveteria, um ambiente lúdico - com a presença de uma cascata de chocolate - e a instalação de uma mini fábrica, onde o turista pode acompanhar a produção do chocolate. No ano de 2012 essa loja passa por reestruturação e, de acordo com Noel, "o principal objetivo foi, ah, a inovação mesmo". Houve mudança da decoração e ambientação, além da ampliação da cafeteria e da sorveteria; reestruturação do cardápio; implantação de novos serviços, como o 'Delícias às Pressas'; reestruturação da mini fábrica. O espaço lúdico também passou por reformas e ganha como anfitriã a figura de uma Camponesa.

Figura 11: A Camponesa da Planalto

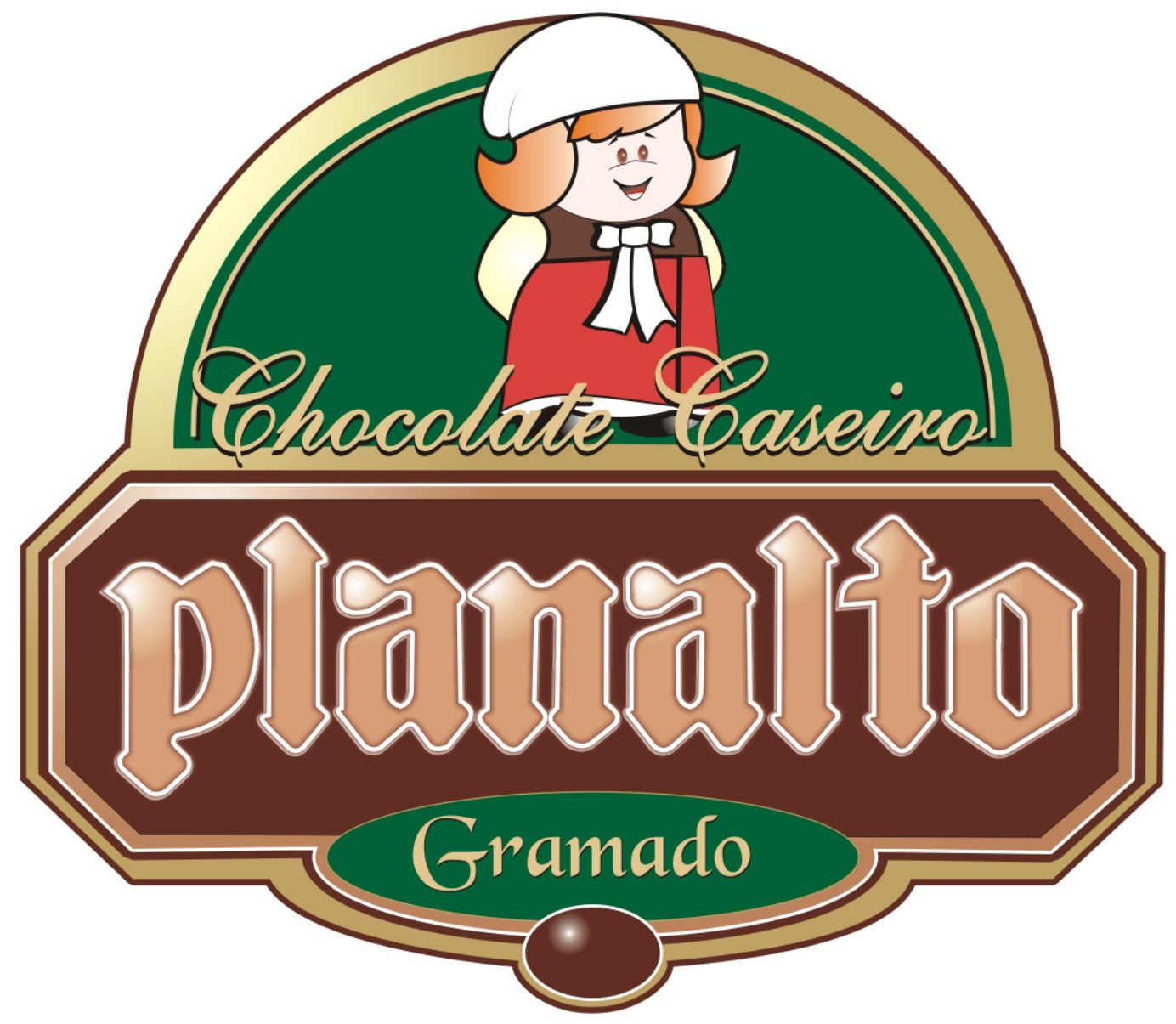

Fonte: www.chocolateplanalto.com.br.

Nos anos seguintes surgiram outras empresas fabricantes: Caracol (em 1982, em Canela, mas se instalando em Gramado em 1999); Chocolate Gramadense (1982); Do Parke (1986); Florybal (1991); Canto Doce (1997); Don Morello (2005); 
Chocolataria Gramado (2010), entre outras. Considerando o número crescente de empresas produtoras de chocolate na cidade, não seria possível, no âmbito de um único artigo, apresentar a história de cada uma delas. No entanto, dentre as empresas mais recentes, é importante reportar à Florybal, por seu diferencial em um mercado hoje bastante competitivo.

A Chocolate Caseiro Florybal foi fundada em 17 de janeiro de 1991 por Valdir e Janete Cardoso. Arminda Bertuzzi recorda que ela "fazia o chocolate [que] era vendido no carro dele de porta em porta. Era um chocolate caseiro". Tiago Cardoso complementa que "eles começaram a fazer aquela coisa muito artesanal ainda". Com o crescimento do negócio, o casal decidiu sair da informalidade e abrir empresa. Como as demais, também esta começou numa área pequena, com $21 \mathrm{~m}^{2}$, inicialmente denominada Florestal. O nome é alterado para Florybal, em 1998, seguindo-se a troca de endereço para instalações maiores no Bairro Floresta, em 2002, endereço em que permanece até a atualidade (FLORYBAL, 2011).

A trajetória da empresa também foi marcada pelo cuidado com as instalações do varejo. Segundo Cardoso, era necessário atrair clientes, especialmente os turistas, para loja. Nas suas palavras: "Como se trata de uma fábrica mais afastada, eles pensaram em criar o transporte gratuito. O transporte era todo tematizado, todo decorado." Além da disponibilização do transporte, entre 2004 e 2005 a empresa passou a decorar de forma tematizada também a fachada da loja da fábrica com o objetivo de misturar:

[...] o Chocolate com o entretenimento, com essa magia. Principalmente criança, é um público que a gente gosta de trabalhar bastante porque a criança vai na loja, já vê aquele chocolate diferente, ela já fica encantada com tudo aquilo, com esse mundo de chocolate por todos os lados e então a gente buscou criar mais um diferencial para dar toda essa emoção, toda essa vida dentro da loja, para o cliente sair encantado realmente" (Tiago Cardoso).

A partir daí, a empresa se lança no mercado de entretenimento turístico. Em $1^{\circ}$ de fevereiro de 2006, a Florybal abre sua loja temática, localizada na Avenida das Hortênsias. Em pouco tempo, incorpora a casa ao lado e cria sua Loja Vip que, além da venda dos produtos, apresenta uma fachada interativa. Um túnel tematizado liga as duas lojas e uma mini fábrica. Seguindo o conceito 
de entretenimento, logo em seguida foi criada, próximo a Canela, município vizinho a Gramado, a Play House Florybal, que, além de loja de chocolate, inclui pista de patinação. Na pista, a base é composta por um gel e há um forte aroma, o que leva à sensação de patinar sobre o chocolate. Segundo Cardoso, a empresa "é a que mais mistura Chocolate e entretenimento. Ela tem a loja de Chocolate e a pista de patinação de Chocolate dentro da loja. É a primeira pista do mundo". No mesmo espaço há o túnel, Território dos Horrores, com diversos cenários e personagens que procuram causar emoção em quem o visita. A Play House também conta com cafeteria cyber com acesso wireless.

Figura 12: Play House Florybal

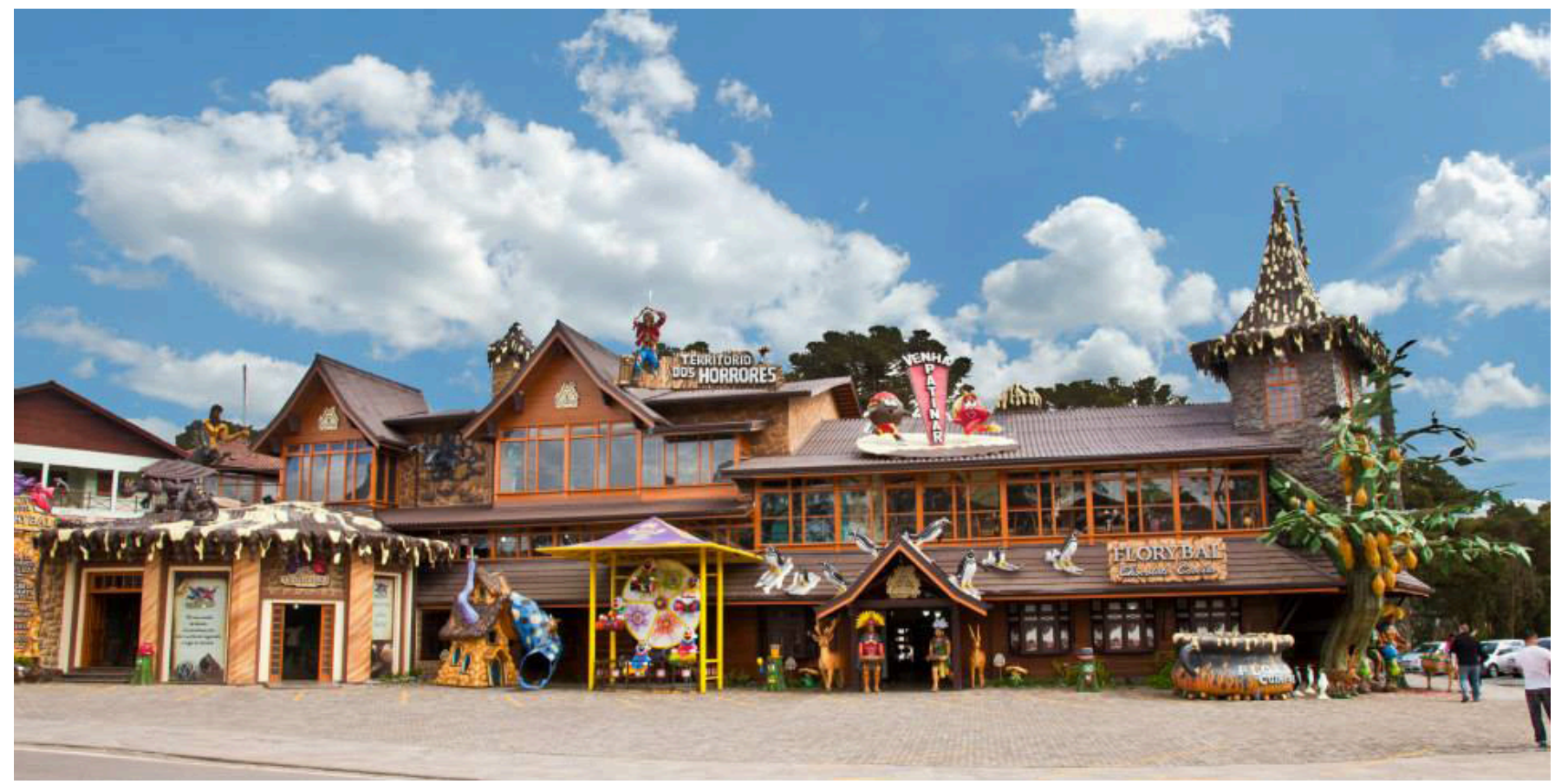

Fonte: www.florybal.com.br.

O investimento no entretenimento ganha força no turismo em Gramado. Nessa linha de trabalho, em dezembro de 2011, a empresa inaugura o Parque Terra Mágica Florybal. Tiago Cardoso explica que "depois de ter criado a primeira loja temática da empresa, começou a surgir esse sonho de ter uma coisa maior, de ter alguma coisa que pudesse brincar mais com isso, que pudesse ter mais esse entretenimento para o turista, esse diferencial na Serra Gaúcha". O empreendimento está localizado na estrada que leva ao Parque do Caracol, em Canela. Possui uma área verde de 67 mil metros quadrados, onde estão esculturas e um cinema 7D, sempre no intuito de associar entretenimento, 
turismo e chocolate. Pezzi (2013), que estudou Gramado sob o ponto de vista da experiência, utilizando-se para tal das dimensões propostas por Pine II e Gilmore (1999), encontrou com destaque a dimensão do entretenimento contribuindo para a experiência memorável. E, na dimensão memória, destacase o cheiro de chocolate nos mesmos termos, segundo sua pesquisa.

O viés do entretenimento também é perseguido pela área de eventos em Gramado, com destaque para o Páscoa em Gramado - Chocofest. Na Páscoa de 2014, "mais de 408 mil pessoas passaram pela cidade nos 19 dias de Chocofest, confirmando-o como o maior evento de Páscoa do Brasil"28. Esse viés mostra que a presença do chocolate em Gramado, que de 'caseiro' se tornou uma indústria poderosa graças ao seu diálogo comercial direto com o turismo, é bastante fecunda. Reforça, também, a fórmula consagrada em associar Turismo, produção industrial e eventos tematizados, com grande sucesso.

\section{CONSIDERAÇÕES FINAIS}

A história do turismo pode significar um importante instrumento para melhor compreensão dos processos contemporâneos de presença da atividade nas localidades. No caso de Gramado, o resgate histórico permite entender que o sucesso e o destaque na área no Brasil não aconteceram por obra do acaso.

A exemplo de muitas outras localidades, cenários naturais de beleza cênica e clima ameno - que ainda hoje contribuem para que dimensão estética da experiência nesta cidade seja considerada pelos turistas como memorável (PEZZI, 2013) - foram importante indutor de atração dos primeiros visitantes. Esses buscavam a localidade nos meses mais quentes do ano - de dezembro a fevereiro -, fugindo do calor em suas localidades de origem, o que fez de Gramado um importante destino de segunda residência. Foram igualmente importantes nas primeiras décadas do séculoXX os ditames da Medicina quando se recomendavam temporadas em locais de maior altitude como benéficos para o tratamento da tuberculose e de outras doenças respiratórias, comuns no período.

Se a natureza integrou a lista privilegiada dos primeiros atrativos, intervenções humanas nesse cenário não deixaram de ser importantes. Projetos 
de loteamentos - com vistas ao turista de segunda residência - incorporaram paisagismo e ajardinamentos, sendo o caso mais significativo o da Vila Planalto. Outras iniciativas introduziram a hortênsia por toda cidade, transformando-a em flor marca da localidade. O acesso ao local, facilitado pela chegada do trem, ampliou a presença de visitantes, incentivando a economia local com a criação de hotéis e restaurantes, que por sua vez consumiam a produção agrícola da área rural. Nota-se, pelos relatos, que igualmente importante foi a postura de muitos veranistas na localidade, que passavam dessa condição a de moradores e, em decorrência, instalando negócios envolvendo artesanato em madeira, em cerâmica e em malhas, numa produção já então voltada para atendimento das demandas dos turistas.

Os momentos de crise do turismo, ao deprimir a economia local, também servem para demonstrar - mesmo que pelo seu lado negativo - a importância da atividade para o desenvolvimento local. Foi assim com a suspensão do trem, nos anos 1950, e a crise do petróleo, na década de 1970, dois momentos em que razões externas à localidade levaram à diminuição da presença de turistas, impactando profundamente a economia local. Esses momentos mostraram que o turismo, independentemente dos dados oficiais que hoje o responsabilizam por 90\% da economia local, é fundamental para Gramado. A crise ocasionada pela suspensão do trem nos anos 1950 trouxe como reação imediata a mobilização da comunidade pela emancipação e criação do Município de Gramado. Criado o município, a primeira providência foi a de incentivar políticas de turismo, que levaram, entre outros, à promoção da $1^{\circ}$ Festa das Hortênsias, cujo principal objetivo era o de atrair de volta os antigos veranistas, agora elevados à condição de turistas, como colocado em um dos depoimentos registrados pela pesquisa.

Na segunda metade do século $X X$, vieram outros eventos, como FEARTE ou mesmo o Festival de Cinema, cuja presença permite uma sistematização importante, ao mostrar que Gramado deve muito do seu sucesso ao associar uma produção industrial local - móveis, malhas, cerâmica - à realização de eventos tematizados a partir dessa produção, mas não só. Significa dizer que os processos industriais locais, ao mesmo tempo em que se tornam atrativos de visitantes, têm nesses mesmos visitantes a base de seus consumidores. A festa temática, então, incentiva tanto a produção como o consumo, numa cadeia 
econômica interdependente, que por sua vez incentivará outros negócios na hospitalidade e na restauração. A área rural não foge à regra, pois passou de fornecedora de hotéis e restaurantes - e mesmo ao turista de segunda residência, segmento novamente importante na cidade, na atualidade - a atrativo turístico rural, mas também presente na área urbana, em muito incentivada pela Festa da Colônia, realizada anualmente em uma das praças centrais de Gramado.

Reforça-se a posição de que no turismo se está diante de um processo no qual há inúmeros fatores intervientes, não só os propriamente turísticos, no sentido mais restrito, mas outros, que seriam fundamentais nas decisões do viajante sobre o que visitar. Como proposto por Beni (2007, p.37), realização pessoal e social; natureza motivacional, econômica, cultural e ecológica, entre outras, ditam a escolha dos destinos, ao lado de componentes como meios de transporte, alojamento e alimentação. Ao que os dados coletados parecem indicar, Gramado investe em todas as pontas do processo, da infraestrutura receptiva à busca por atender às demandas psicossociais dos visitantes por uma experiência diferenciada é única (PEZZI, 2013).

A presença historicamente mais recente - do chocolate caseiro - é um momento novo, mas também significativo do que se está tentando demonstrar da interdependência de setores produtivos com o turismo. O empresário Jayme Prawer, que introduziu o chocolate caseiro em Gramado como um novo segmento produtivo está entre os que, de turistas de segunda residência, implantam negócios próprios na cidade, no seu caso iniciado pela Churrascaria Bela Vista e pelo Café Colonial de mesmo nome. O chocolate nasce nos anos 1970 como um pequeno negócio, com três funcionários, para em quatro décadas tornar-se destaque nas intensões de comprar no local. Fortemente agregado à marca Gramado e à sua paisagem urbana atual pela presença de inúmeras lojas, o seu percurso de presença fica bem caracterizado no depoimento de uma atendente de loja de chocolate durante o trabalho de campo da pesquisa, a qual afirmou: "Chocolate é tudo. É pobre, é médio, é rico. O turista não compra uma lembrancinha, ele compra um Chocolate".

Da fábrica original, hoje seriam mais de 20 estabelecimentos, não se considerando aqueles que se mantêm na informalidade, o que indica um cenário bastante competitivo. Um cenário no qual se observam duas tendências: de 
um lado as empresas que reforçam o imaginário de caseiro no seu produto e pontos de venda, onde a decoração do espaço se marca pelo tradicional e pelas cores sóbrias; na outra ponta, empresas que trabalham de maneira extrema a tematização, em que o chocolate, para além do produto alimentício, é inspiração para parques temáticos, pista de patinação e outras formas de entretenimento.

Muitas estratégias foram realizadas pelas empresas chocolateiras e por seus gestores, para que se chegasse ao cenário atual do produto, indicando ser o chocolate um bem agregado à marca Gramado, de forma espontânea ou eficientemente trabalhada. Em termos de agregação à marca, o ser de Gramado foi utilizado por Prawer, que destacava em suas embalagens símbolos do local, como as Hortênsias e a arquitetura. Aliás, Prawer segue estratégias estabelecidas em outros momentos, quando móveis e outros objetos em madeira eram produzidos pelo Artesanato Gramadense e caracterizavam um design que passou a ser denominado como Estilo Gramado. Consagrado, será a vez de o produto contribuir para qualificar a marca, como se deu com o setor moveleiro e cerâmico em outros tempos. O processo de associação à marca Gramado e a outros produtos já consagrados do local, como o Festival de Cinema, que num primeiro momento teria beneficiada a introdução do Chocolate, em momentos seguintes se inverteram, e o chocolate passa a beneficiar a cidade. Exemplificando, o chocolate agrega Gramado, para depois Gramado ser sinônimo de chocolate e, como mostram as pesquisas de intensão de compras e de expectativa para retorno à região, beneficiar a ambos em termos de turismo.

Repete-se, de maneira ampliada, o modelo consagrado em que a indústria local, o turismo e os eventos temáticos associam-se e são interdependentes. Hoje, o campo se torna mais complexo, pois à realização de eventos tendo por objeto o chocolate, registra-se a sua associação com entretenimento. São estratégias que foram, e são, trabalhadas para criar e reforçar a identificação do produto com Gramado, tornando o chocolate em um símbolo da cultura local. Gramado torna-se a 'terra do chocolate', refletindo diretamente no turismo à medida que as pessoas compram e consomem esse produto, frequentam os parques e as lojas e remetem que o chocolate de Gramado "é tudo" e um pouco mais. Um conceito a ser relativizado numa visão mais crítica. 
ALBERTI, V. Manual de história oral. Rio de Janeiro: FGV, 2004.

BENI, M.C. Análise estrutural do Turismo. São Paulo: Editora Senac, 2007.

BOYER, M. História do turismo de massa. Bauru: Edusc, 2003

CASAGRANDE, G.R. Um cheiro do vinho: presença italiana em Gramado. Dissertação (Mestrado em História) PUCRS Faculdade de Filosofia e Ciências Humanas. Porto Alegre, 2006.

DALONSO, YS; LOURENÇO, J; REMOALDO, PCA; CYRILLO, M. O papel do Plano Diretor na constituição das políticas públicas para o turismo: um estudo da cidade de Gramado, Rio Grande do Sul (Brasil). Revista Turismo e Desenvolvimento v. 2, n. 17-18, 2012, p 909 923.

FIGUEIREDO, F.B. Gastronomia e hibridismo cultural de restaurantes italianos em Gramado RS: Estudo de caso. CULTUR: Revista de Cultura e Turismo, ano 3, n. 1, 2009

DA ROSA, A.G. Medida de Expectativa de Auto Eficácia para o Turismo de Lazer: Desenvolvimento, Confiabilidade e Validade de Construto. Dissertação (Mestrado em Turismo). Universidade de Caxias do Sul. Caxias do Sul, 2006.

GRAMADO - SECRETARIA MUNICIPAL DE EDUCAÇÃO. Gramado, Simplesmente Gramado. Prefeitura Municipal, 1987.

INSTITUTO BRASILEIRO DE GEOGRAFIA E ESTATÍSTICA. Disponível em: < http://www.ibge. gov.br/cidadesat/topwindow.htm?1 >. Acesso em: 30 nov. 2011.

LEMOS, S.F.; BENI, M. Fatores indutores d fidelidade do turista dos hotéis na cidade de Gramado, RS. Turismo Visão e Ação, a. 4, n. 10, 2001-2002, pp.117-120.

MINISTÉRIO DO TURISMO. Índice de Competitividade do Turismo Nacional - 65 Destinos Indutores: Estudo de Competitividade dos 65 Destinos Indutores - 2010. Disponível em: <http://www.Turismo.gov.br/Turismo/o_ministerio/publicacoes/cadernos _publicacoes/00estudos_indutores.html >. Acesso em: 26 out. 2011.

MINISTÉRIO DO TURISMO. Marcos Conceituais. Disponível em: < http://www.Turismo.gov. br/Turismo/o_ministerio/publicacoes/cadernos publicacoes/14manuais.html $>$. Acesso em: 26 out. 2011. 
PEZZI, E. Turismo e Experiência: Um Estudo sobre as Dimensões da Experiência Memorável em Gramado, RS. Dissertação (Mestrado em Turismo) Universidade de Caxias do Sul. Programa de Pós-Graduação em Turismo. Caxias do Sul, 2013.

PINE II, B. J.; GILMORE, J. H. The experience economy: work is theatre and every business a stage. Boston: Harvard Business School Press, 1999.

PRAWER. Chocolates Prawer 35 anos: a trajetória de um pioneiro. Gramado, 2010.

REJOWSKI, M. Turismo no percurso do tempo. São Paulo: Aleph, 2002.

SIQUEIRA, L. A microanálise na pesquisa em história do turismo. Revista Hospitalidade, São Paulo, ano V, n. 1, 2008, p.117-130.

TOMAZZONI, E.L; BOCK, I.A; SIMON, S. Caminhos da Colônia: Turismo Rural na Serra GaúchaRS, Brasil. Revista Rosa dos Ventos, V.4 (2), 2012, pp. 250-262.

TOWNER, J. Approaches to tourism history. Annals of Tourim Research, V. 15, 1988, pp. 47-62.

TOWNER, J. What is tourism's history? Tourism Management, V.16 (5), 1995, pp. 339-343.

URRY, J. O olhar do turista: lazer e viagens nas sociedades contemporâneas. São Paulo: SESC, Studio Nobel, 1999.

WALTON, J.K. Welcome to the Journal of Tourism History. Journal of Tourism History, V.1 (1), 2009, pp.1-6.

FONTES DE PESQUISA

\section{FONTES DOCUMENTAIS ELETRÔNICAS}

FLORYBAL. Informativo Chocolate Caseiro Florybal. Linha do Tempo: Especial 20 anos, 2011.

GRAMADO. Prefeitura Municipal. A Cidade. Disponível em: < $\underline{\text { http://www.gramado.rs.gov. }}$ br/index.php/Gramado/A-Cidade.html>. Acesso em: 30 set. 2011.

GRAMADO. Prefeitura Municipal. Notícias. Disponível em: < http://www.gramado.rs.gov.br/ index.php/Turismo/Gramado-celebra-seus-58-anos.html>. Acesso em: 13 abr. 2013.

PLANALTO. Disponível em: <http://www.chocolateplanalto.com.br/site novo/planalto. 


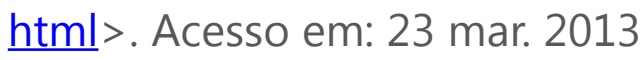

ABICAB - Associação Brasileira da Indústria de Chocolates, Cacau, Amendoim, Balas e Derivados. Disponível em <http://www.abicab.org.br/en>. Acesso em: 10 out. 2013.

Chocofest - Disponível em <http://www.chocofest.com.br/>. Acesso em: 10 out. 2013.

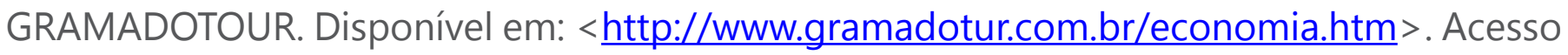
em: 25 mar. 2013

\section{ENTREVISTAS}

- Arminda Bertuzzi: Foi assessora de imprensa da Chocolate Caseiro Florybal. Entrevistada em 17.12.2012.

- Bernardete Porti: Trabalhou na Chocolate Prawer, quando da sua criação. Entrevistada em 22.01.2013.

- Cristina Petry: Secretária geral da Chocofest, evento produzido pela empresa Marta Rossi e Silvia Zorzanello Feiras e Empreendimentos, entrevistada em 22.01.2013.

- Débora Leobet Noel: Psicóloga e gerente da Loja da Chocolate Planalto localizada na Avenida Borges de Medeiros. Entrevistada em 03.08.2012.

- Enor Francisco Terres da Luz: Diretor da empresa Chocolate Lugano, entrevistado em 05.03.2012.

- Gilnei Ricardo Casagrande: Filho do fundador da Chocolate Lugano e diretor do Arquivo Público Municipal Leopoldo Lied, quando da entrevista em 15.02.2012.

- Glaucia Nielsen: Jornalista na empresa Marta Rossi e Silvia Zorzanello Feiras e Empreendimentos, entrevistada em 22.01.2013.

- Luciane Schommer: Empresária na área de eventos, comunicação e turismo, entrevistada em 20.12.2012.

- Luiz Carlos Caio Tomazelli: Diretor da Chocolate Prawer por trinta anos, fundador da Associação dos Chocolateiros (ACHOCO) e idealizador e coordenador do Congresso Latinoamericano do Chocolate (CHOLATINO) e da Feira Brasileira do Chocolate (FEBRACHOCO). Também foi secretário do Turismo de Gramado. Entrevistado em 05.03.2012.

- Marcus Vinícius Rossi: Diretor geral da empresa Marta Rossi e Silvia Zorzaello Feiras e Empreendimentos. Entrevistado em 04.02.2013. 
- Marta Rossi: Diretora presidente da Marta Rossi e Silvia Zorzanello Feiras e Empreendimentos, entrevistada em 04.02.2013.

- Martina Nunes: Trabalhou em uma empresa fabricante de chocolate em Gramado/RS. Entrevistada em 22.01.2013.

- Nadia Prawer: Filha do fundador da Chocolates Prawer e diretora de Marketing da empresa, entrevistada em 06.03.2012.

- Norma Martini Moesch: Diretora da Secretaria de Turismo do Estado do Rio Grande do Sul, na década de 1970, entrevistada em 03.08.2012.

- Tiago Cardoso: Assistente de marketing Chocolate Caseiro Florybal, entrevistado em 15.02.2012.

\section{DEPOIMENTOS ESCRITOS}

BEHREND, I. sem título. In: GRAMADO. Raízes de Gramado. Gramado, 1999.

BERTOLUCCI, J.L. Leopondo Rosenfeldt. In: GRAMADO. Raízes de Gramado. Gramado, 1999.

DINNEBIER, I. Setor Moveleiro. In: GRAMADO. Raízes de Gramado. Gramado, 1999.

KNORR, I.K. Parque Knorr: por um ideal. DAROS, M.; BARROSO, V.L.M. (Org.). Raízes de Gramado - $\mathbf{4 0}$ anos. Porto Alegre: EST, 2000.

KOHUT, K. WANKLER, P., HABERLER, S., WEBER, R. A participação da hotelaria no desenvolvimento de Gramado. In: DAROS, M.; BARROSO, V.L.M. (Org.). Raízes de Gramado - 40 anos. Porto Alegre: EST, 2000, pp. 115-119.

RIEGEL, R.E. Quatro raízes e uma árvore. In: DAROS, M.; BARROSO, V.L.M. (Org.). Raízes de Gramado - $\mathbf{4 0}$ anos. Porto Alegre: EST, 2000, pp. 25-31.

RUBIM, R. Artesanato Gramadense: Breve relato. In: GRAMADO. Raízes de Gramado. Gramado, 1999.

SIQUEIRA, Lucília. A microanálise na pesquisa em história do turismo. Revista Hospitalidade, São Paulo, ano V, n. 1, p. 117-130, 2008.

SPARREMBERGER, I. A identidade cultural de Gramado. In: In: DAROS, M.; BARROSO, V.L.M. (Org.). Raízes de Gramado - 40 anos. Porto Alegre: EST, 2000, pp. 137-139.

1 Trata-se de livro organizado e editado pela Prefeitura de Gramado, reunindo depoimentos de pessoas sobre a história do município. 
- Folhetearias promocionais das empresas produtoras de Chocolate de Gramado.

- Jornal da Chocofest, edição de março de 2012.

- Revista Turminha da Florybal, Set/2011.

- Informativo da Chocolate Florybal. Linha do Tempo Especial 20 anos, 2011.

- FEBRACHOCO - Feira Brasileira do Mercado de Chocolate, flyer mapa e programação 2011.

- Jornal Pioneiro, 29 de junho de 2012, edição impressa.

\section{NOTAS}

1 The conventional view of tourism's past is dominated by the history of western cultural experience. [...]. This paper argues that more attention should be paid to tourism's past in nonwestern societies and cultures and to the more ordinary and routine practices of a wider crosssection of the population.

2 Importante contribuição tem sido dada, nestes termos, nos congressos e seminários da ANPUH e da ANPTUR, ao criarem grupo e núcleos dedicados à História do Turismo e das Viagens, no Brasil, dando visibilidades a muitos estudos sobre o tema.

3 Disponível em http://www.conventionbureau.com.br/novo-pesquisas/. Acesso em: 23 jan.2015.

4 Disponível em http://www.conventionbureau.com.br/novo-pesquisas/. Acesso em: 23 jan.2015.

5 Disponível em http://www.conventionbureau.com.br/novo-pesquisas/. Acesso em: 23 jan.2015.

6 O livro Raízes de Gramado foi editado pela Secretaria de Educação da Prefeitura Municipal de Gramado em 1999, reunindo uma série de depoimentos sobre a história da cidade, desde os seus primórdios permeada pelo Turismo, como o presente texto apresentará adiante. A outra obra, Raízes de Gramado - V Encontro dos Municípios originários de Santo Antônio da Patrulha, de 2000, reúne trabalhos - muitos deles depoimentos - apresentados no referido Encontro. Não se trata, portanto, de material de divulgação da Prefeitura, mas de livro por ela editado, com conteúdos independes.

$7 \quad$ Lista completa dos entrevistados, no final deste, em Fontes de Pesquisa.

8 Ver relação completa, junto às Referências Bibliográficas e de Fontes de Pesquisa.

$9[\ldots]$ a study of tourism in the past may be primarily to provide examples which will contribute 
to a dynamic model or concept of the role of tourism in societies in general. In other words, the historian's aim is to reconstruct the reality of a particular past period or event, while the social scientist aims to develop more general concepts of society where the specific historicity of the data is not of central importance [...]. (TOWNER, 1988, p. 50).

10 Ver <http://www.abeoc.org.br/2013/01/gramado-rs-recebe-57-milhoes-de-turistas-em2012/>, acesso em 31/01/14. Jornal de Gramado. Versão online, em 12.01.2013. Disponível em: <http://www.jornaldegramado.com.br/turismo/434118/gramado-recebeu-mais-de-5-7milhoes-de-visitantes-em-2012.html> . Acesso em: 16 abr. 2013. Não encontramos, disponibilizados, dados de 2013 ou 2014.

11 IBGE CIDADES, disponível em http://cidades.ibge.gov.br/xtras/perfil.php?lang=\&codmun=43 0910\&search=\|linfogr\%E1ficos:-informa\%E7\%F5es-completas. Acesso em: 30 jan. 2015.

12 Chamando no Google a expressão 'Gramado Alemã', aparecem 858.000 entradas, em consulta em 27 jan. 2015.

13 Disponível em <http://gramadomagazine.com.br/revista/revista1.php?c=238>. Acesso em: 20 abr. 2014.

14 Disponível em <http://www.achetudoeregiao.com.br/rs/gramado/historia.htm>. Acesso em 15 jan. 2014.

15 Disponível em <http://gramadomagazine.com.br/revista/revista1.php?c=238>. Acesso em: 20 abr. 2014.

16 Destaca-se a figura de Oscar João Knorr, que incentivou o cultivo da Hortênsia em Gramado. Na cidade, criou o atual Parque Knorr, hoje um dos principais pontos turísticos da cidade (KNORR, 2000).

17 Disponível em < http://www.gramadotur.com.br/economia.htm>, acesso em 27 Jan 2015.

18 Disponível em: <http://www.gramadotur.com.br/economia.htm>. Acesso em: 25 mar. 2013.

19 Disponível em: < http://www.gramadotur.com.br/economia.htm>. Acesso em: 25 mar. 2013.

20 Disponível em <http://www.gramado.rs.gov.br/index.php/Simbolos-do-Municipio/Historia. html>. Acesso em: 16 abr. 2013. Ver, também, figuras 1, 2 e 3 no corpo do texto.

21 Primeira fábrica de Chocolate instalada no Brasil, na cidade de Porto Alegre/RS.

22 Disponível em <http://chocolatesprawer.blogspot.com.br/>. Acesso em: 20 jan.2014.

23 A pesquisa, a partir de informações oficiais da Prefeitura Municipal, registrou 16 fábricas em 2013. Em < http://www.gramadotur.com.br/economia.htm>, acesso em: 27 jan. 2015, encontra-se menção à 19 fábricas. Registre-se, entretanto, que o setor ainda apresenta muita informalidade, podendo-se inferir que esses números sejam bem maiores.

24 Mentinha é um dos tipos de Chocolate produzido pela Prawer. São pequenos tabletes feitos com Chocolate meio amargo e suave essência de menta.

25 Análise de Perigos e Pontos Críticos de Controle (ou HACCP - Hazard Analysis and Critical Control Points) é um método utilizado pela indústria de alimentos que tem como pré-requisito as Boas Práticas de Fabricação. O propósito do mesmo é garantir a produção de alimentos seguros, do ponto de vista higiênico-sanitário, para o consumidor. 
DoI: 10.14210/rtva.v17n1.p66-102

26 Disponível em <http://www.proper.com.br/portfolio/embalagem/2.jpg>. Acesso em: 27 out. 2013.

27 Disponível em < http://mapadomundo.org/gramado/chocolate-lugano-loja-tematica-e-fabrica/>. Acesso em 20 jan. 2015.

28 Coluna Painel Econômico, assinada pelo jornalista Danilo Ucha (Jornal do Comércio, 30/04 e 01/05/2014, p. 6). 